NASA/TM-2000-209891, Vol. 109

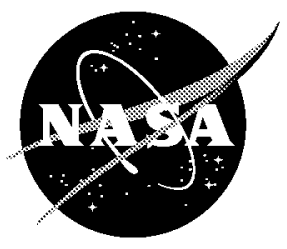

Technical Report Series on the Boreal Ecosystem-Atmosphere Study (BOREAS)

Forrest G. Hall, Editor

\title{
Volume 109
}

\section{BOREAS Regional Soils Data} in Raster Format and AEAC Projection

Bryan Monette, Agriculture Canada, Ottawa, Ontario, Canada

David Knapp, Raytheon ITSS, NASA Goddard Space Flight Center,

Greenbelt, Maryland

National Aeronautics and

Space Administration

Goddard Space Flight Center

Greenbelt, Maryland 20771 
The NASA STI Program Office ... in Profile

Since its founding, NASA has been dedicated to the advancement of aeronautics and space science. The NASA Scientific and Technical Information (STI) Program Office plays a key part in helping NASA maintain this important role.

The NASA STI Program Office is operated by Langley Research Center, the lead center for NASA's scientific and technical information. The NASA STI Program Office provides access to the NASA STI Database, the largest collection of aeronautical and space science STI in the world. The Program Office is also NASA's institutional mechanism for disseminating the results of its research and development activities. These results are published by NASA in the NASA STI Report Series, which includes the following report types:

- TECHNICAL PUBLICATION. Reports of completed research or a major significant phase of research that present the results of NASA programs and include extensive data or theoretical analysis. Includes compilations of significant scientific and technical data and information deemed to be of continuing reference value. NASA's counterpart of peer-reviewed formal professional papers but has less stringent limitations on manuscript length and extent of graphic presentations.

- TECHNICAL MEMORANDUM. Scientific and technical findings that are preliminary or of specialized interest, e.g., quick release reports, working papers, and bibliographies that contain minimal annotation. Does not contain extensive analysis.

- CONTRACTOR REPORT. Scientific and technical findings by NASA-sponsored contractors and grantees.
- CONFERENCE PUBLICATION. Collected papers from scientific and technical conferences, symposia, seminars, or other meetings sponsored or cosponsored by NASA.

- SPECIAL PUBLICATION. Scientific, technical, or historical information from NASA programs, projects, and mission, often concerned with subjects having substantial public interest.

- TECHNICAL TRANSLATION. English-language translations of foreign scientific and technical material pertinent to NASA's mission.

Specialized services that complement the STI Program Office's diverse offerings include creating custom thesauri, building customized databases, organizing and publishing research results ... even providing videos.

For more information about the NASA STI Program Office, see the following:

- Access the NASA STI Program Home Page at http://www.sti.nasa.gov/STI-homepage.html

- E-mail your question via the Internet to help@sti.nasa.gov

- Fax your question to the NASA Access Help Desk at (301) 621-0134

- Telephone the NASA Access Help Desk at (301) 621-0390

- Write to:

NASA Access Help Desk

NASA Center for AeroSpace Information 7121 Standard Drive Hanover, MD 21076-1320 
NASA/TM-2000-209891, Vol. 109

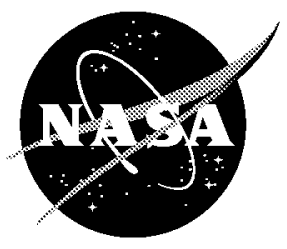

Technical Report Series on the Boreal Ecosystem-Atmosphere Study (BOREAS)

Forrest G. Hall, Editor

\section{Volume 109}

\section{BOREAS Regional Soils Data} in Raster Format and AEAC Projection

Bryan Monette, Agriculture Canada, Ottawa, Ontario, Canada

David Knapp, Raytheon ITSS, NASA Goddard Space Flight Center,

Greenbelt, Maryland

National Aeronautics and

Space Administration

Goddard Space Flight Center

Greenbelt, Maryland 20771 


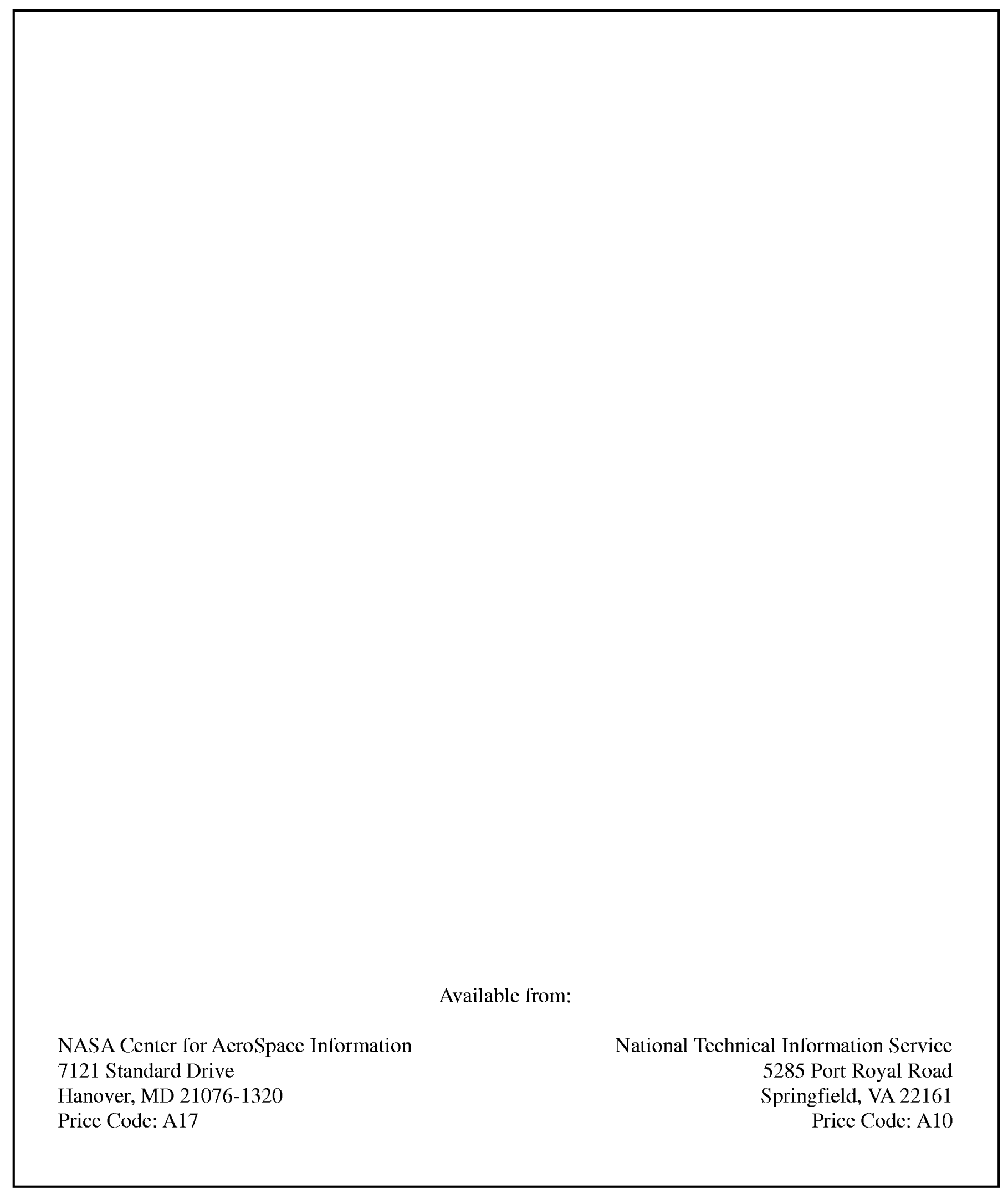




\title{
BOREAS Regional Soils Data in Raster Format and AEAC Projection
}

\author{
Bryan Monette, David Knapp
}

\section{Summary}

This data set was gridded by BORIS Staff from a vector data set received from the Canadian Soil Information System (CanSIS). The original data came in two parts that covered Saskatchewan and Manitoba. The data were gridded and merged into one data set of 84 files covering the BOREAS region. The data were gridded into the AEAC projection. Because the mapping of the two provinces was done separately in the original vector data, there may be discontinuities in some of the soil layers because of different interpretations of certain soil properties. The data are stored in binary, image format files.

Note that the binary files of this data set on the BOREAS CD-ROMs have been compressed using the Gzip program. See Section 8.2 for details.

\section{Table of Contents}

1) Data Set Overview

2) Investigator(s)

3) Theory of Measurements

4) Equipment

5) Data Acquisition Methods

6) Observations

7) Data Description

8) Data Organization

9) Data Manipulations

10) Errors

11) Notes

12) Application of the Data Set

13) Future Modifications and Plans

14) Software

15) Data Access

16) Output Products and Availability

17) References

18) Glossary of Terms

19) List of Acronyms

20) Document Information

\section{Data Set Overview}

\subsection{Data Set Identification}

BOREAS Regional Soils Data in Raster Format and AEAC Projection

\subsection{Data Set Introduction}

The Inventory Section of the Land Resource Research Centre (LRRC) undertook an effort to compile a computerized data base to record the attributes of the soil and land for all of Canada and to prepare maps from this information at a scale of 1:1,000,000. The compilation was done by standard methods, and the maps were divided into unit areas called polygons. Each polygon is described in terms of a standard set of attributes. These attributes are the factors considered most important for plant growth, general land management, regional planning, terrain sensitivity, and environmental sustainability. The array of attributes that describe a distinct type of soil and its associated 
characteristics, such as landform, slope, water table, permafrost, and lakes, is called a soil landscape. A polygon may contain one or two distinctive soil landscapes, as well as small but contrasting inclusions. These vector data from LRRC served as the basis for this raster format data product.

The original manual documents the standard methods and descriptors used by all provinces for compilation of a national soil landscape data base at a scale of 1:1,000.000.

\subsection{Objective/Purpose}

These raster format soils data are provided as part of the BOReal Ecosystem-Atmosphere Study (BOREAS) Staff Science Geographic Information System (GIS) Data Collection Program, which included the collection of pertinent map data in both hardcopy and digital form. This data set, originally provided as vector polygons with attributes, has been processed to provide raster files that can be used for modeling or for comparisons.

\subsection{Summary of Parameters}

The parameters contained in the 82 files of the raster soil data include:

Provincial Code

Polygon Number

Kind of Rock Outcrop or other material at the surface

Percentage distribution of soil landscapes

Regional landform

Local surface form

Slope gradient class

Parent material mode of deposition

Parent material texture

Soil development

Surface texture of mineral soil to $15 \mathrm{~cm}$

Coarse fragment content in control section

Rooting depth, unrestricted

Kind of compacted, consolidated, or contrasting layer

Depth to compacted, consolidated, or contrasting layer

Drainage class

Available water capacity in upper $120 \mathrm{~cm}$

Depth to water table, average

Ice type

Ice content

Permafrost occurrence

Active layer depth in soils with permafrost

Kind of patterned ground in soils with permafrost

$\mathrm{pH}$ of upper $15 \mathrm{~cm}$ of soil $\left(\mathrm{CaCl}_{2}\right)$

$\mathrm{pH}$ of upper $15 \mathrm{~cm}$ of soil (water)

Organic carbon of upper $15 \mathrm{~cm}$

Nitrogen content of upper $15 \mathrm{~cm}$ of soil

Thickness of humus layer

Calcareous class of parent material

Inclusions 1

Inclusions 2

Vegetative cover and/or land use

Lake size from Landsat

Water bodies from Landsat as percentage of polygon

Reliability class of polygon

Complexity class of polygon

Soil name 1

Soil name 2

Parent material textural group 


\subsection{Discussion}

The documentation for the original data listed the following uses for which these data were intended:

- Assess the productivity of the land nationally or over large regions.

- $\quad$ Find areas that have actual or potential problems affecting land use, such as salinity or susceptibility to erosion, and assess the severity.

- Locate general areas that may be suitable for particular types of land use, which can be selected for more detailed investigations.

- Apply general research findings and agrotechnology procedures that are successful in one part of the country to other areas that have similar attributes.

- Link soil and land information with other data bases, such as information on climate, economics, or census, for assessing land use on a regional, national, or even an international scale.

- $\quad$ Educate geography students at colleges or universities.

The framework for the legend development, map compilation, and attribute characterization is established by the following concepts and definitions:

- $\quad$ The maps are composed of map delineations called polygons, each of which is described in terms of a standard set of attributes.

- The full array of polygon attributes that describe a distinct type of soil and its associated landscape attributes, such as surface form, slope, water table, permafrost, and lakes, is called a soil landscape.

- A polygon may contain one or two distinctive soil landscapes (dominant or subdominant) and may also contain a small but contracting proportion of inclusions.

- The dominant (or most prominent) soil landscape represents at least $40 \%$ of the polygon area, whereas the subdominant soil landscape represents only from 16 to $<40 \%$ of the polygon; inclusions represent a maximum of $15 \%$ of the polygon. A more detailed description of the complex map polygons is given in Section 7.

- One or two inclusions can be recorded for each dominant and subdominant soil landscape, but in total they represent only a maximum of $15 \%$ of the polygon area.

- The attributes that separate one polygon from another include (a) soil development, (b) soil parent material mode of deposition, (c) texture class of parent material, (d) local surface form, (e) slope gradient class in percent, (f) kind of rock or surface material except water, and (g) spatial occurrence of these attributes within a polygon. These attributes may apply to either the dominant or subdominant soil landscape.

- The minimum size of the soil landscape area (or polygon) should be about $1 \times 1 \mathrm{~cm}$ at the 1:1,000,000 scale $\left(100 \mathrm{~km}^{2}\right)$; however, smaller, isolated areas that can be conveniently displayed and labeled on the map are permitted when needed.

\subsection{Related Data Sets}

Agriculture Canada Central Saskatchewan Vector Soils Data

BOREAS Soils Data over the SSA in Raster Format and AEAC Projection

CanSIS Regional Soils Data in Vector Format

\section{Investigator(s)}

\subsection{Investigator(s) Name and Title BOREAS Staff Science}

\subsection{Title of Investigation}

BOREAS Staff Science GIS Data Collection Program 


\subsection{Contact Information}

\section{Contact 1:}

Bryan Monette

Agriculture Canada

Ottawa, Ontario

K1A 0C6

(613) 995-5011

\section{Contact 2:}

David Knapp

Raytheon ITSS

NASA GSFC

Code 923

Greenbelt, MD 20771

(301) 286-1424

(301) 286-0239 (fax)

David.Knapp@gsfc.nasa.gov

\section{Theory of Measurements}

The Inventory Section of the LRRC compiled a computerized data base to record the attributes of the soil and land for all of Canada and to prepare maps from this information at a scale of 1:1,000,000. The compilation was done by standard methods, and the maps were divided into unit areas called polygons. Each polygon is described in terms of a standard set of attributes. These attributes are the factors considered most important for plant growth, general land management, regional planning, terrain sensitivity, and environmental sustainability. The array of attributes that describe a distinct type of soil and its associated characteristics, such as landform, slope, water table, permafrost, and lakes, is called a soil landscape. A polygon may contain one or two distinctive soil landscapes, as well as small but contrasting inclusions. The original uses for which these data were intended include:

- Assess the productivity of the land nationally or over large regions.

- Find areas that have actual or potential problems affecting land use, such as salinity or susceptibility to erosion, and assess the severity.

- Locate general areas that may be suitable for particular types of land use, which can be selected for more detailed investigations.

- Apply general research findings and agrotechnology procedures that are successful in one part of the country to other areas that have similar attributes.

- Link soil and land information with other data bases, such as information on climate, economics, or census, for assessing land use on a regional, national, or even an international scale.

- $\quad$ Educate geography students at colleges or universities.

\section{Equipment}

\subsection{Sensor/Instrument Description}

It is known that the original vector data were compiled by interpreting Landsat images, conducting aircraft and field traverses, and digitizing the compiled maps. The exact equipment and related specifications are unknown.

\subsubsection{Collection Environment Unknown.}




\subsubsection{Source/Platform}

Unknown.

\subsubsection{Source/Platform Mission Objectives}

Unknown.

\subsubsection{Key Variables}

The key variables that are in this raster data set include:

Provincial Code

Polygon Number

Kind of Rock Outcrop or other material at the surface

Percentage distribution of soil landscapes

Regional landform

Local surface form

Slope gradient class

Parent material mode of deposition

Parent material texture

Soil development

Surface texture of mineral soil to $15 \mathrm{~cm}$

Coarse fragment content in control section

Rooting depth, unrestricted

Kind of compacted, consolidated, or contrasting layer

Depth to compacted, consolidated, or contrasting layer

Drainage class

Available water capacity in upper $120 \mathrm{~cm}$

Depth to water table, average

Ice type

Ice content

Permafrost occurrence

Active layer depth in soils with permafrost

Kind of patterned ground in soils with permafrost

$\mathrm{pH}$ of upper $15 \mathrm{~cm}$ of soil $\left(\mathrm{CaCl}_{2}\right)$

$\mathrm{pH}$ of upper $15 \mathrm{~cm}$ of soil (water)

Organic carbon of upper $15 \mathrm{~cm}$

Nitrogen content of upper $15 \mathrm{~cm}$ of soil

Thickness of humus layer

Calcareous class of parent material

Inclusions 1

Inclusions 2

Vegetative cover and/or land use

Lake size from Landsat

Water bodies from Landsat as percentage of polygon

Reliability class of polygon

Complexity class of polygon

Soil name 1

Soil name 2

Parent material textural group

\subsubsection{Principles of Operation} Unknown.

\subsubsection{Sensor/Instrument Measurement Geometry Unknown.}




\subsubsection{Manufacturer of Sensor/Instrument}

Unknown.

\subsection{Calibration}

\subsubsection{Specifications}

Unknown.

\subsubsection{Tolerance}

Unknown.

\subsubsection{Frequency of Calibration}

Unknown.

\subsubsection{Other Calibration Information}

Unknown.

\section{Data Acquisition Methods}

The original vector soils data were compiled using various data sources and techniques including:

- Interpretation of Landsat images (it is unknown whether the Landsat images were from the Multispectral Scanner (MSS) or Thematic Mapper (TM) instruments)

- $\quad$ Soil survey maps produced from field traverses at wide intervals (up to $10 \mathrm{~km}$ ) and without the use of aerial photographs

- $\quad$ Maps produced by inspections using fixed-wing aircraft or helicopter and aided by interpretation of Landsat imagery

- $\quad$ Systematic traverses by helicopter and interpretation of stereoscopic aerial photographs

- Modern soil survey procedures, which include traversing existing accessible roads in wilderness areas, and aided by interpretation of stereoscopic aerial photographs

- Modern soil survey maps produced from field traverses at $<1.6-\mathrm{km}$ intervals and with the aid of stereoscopic aerial photographs.

The original data were acquired in ARC/INFO EXPORT format in a vector form. The dominant and subdominant attributes were included in a separate table that was linked to the digital map data by the polygon number.

\section{Observations}

\subsection{Data Notes}

The original vector data are documented fully in:

Soil Landscapes of Canada

Procedures Manual and User's Handbook

J.A. Shields, C. Tarnocai, K.W.G. Valentine, and K.B. MacDonald

Land Resource Research Centre

Ottawa, Ontario

\subsection{Field Notes}

See: derived from reading: 
Soil Landscapes of Canada

Procedures Manual and User's Handbook

J.A. Shields, C. Tarnocai, K.W.G. Valentine, and K.B. MacDonald

Land Resource Research Centre

Ottawa, Ontario

BOREAS Information System (BORIS) personnel assume that extensive field notes exist from compiling the soils information into maps. The details of these notes are unknown.

\section{Data Description}

\subsection{Spatial Characteristics}

The original vector data in ARC/INFO format were gridded into a binary image format for the BOREAS region $(1,000 \times 1,000 \mathrm{~km})$. The original data were digitized from maps at a scale of 1:1,000,000. The cell size at which these data are gridded is 1,000 meters on a side. There are 40 attributes or "items" that describe the dominant and 40 of many of the same attributes for the subdominant soil characteristics. Most of the items were gridded, with the exception of a few items that were inappropriate to grid (e.g., urban areas, water).

\subsubsection{Spatial Coverage}

These data cover the 1,000-km x 1,000-km area defined as the BOREAS Grid Region. It forms a rectangle that roughly straddles the Saskatchewan/Manitoba border with corner coordinates of $0.0,0.0$ and 1000.0, 1000.0 in the Albers Equal-Area Conic (AEAC) projection described in the BOREAS Experiment Plan. The following are the corner coordinates of the BOREAS region, given in the North American Datum of 1983 (NAD83):

$\begin{array}{lrr} & \text { Longitude } & \text { Latitude } \\ & -------- & ------- \\ \text { Northwest } & 111.000 \mathrm{~W} & 59.979 \mathrm{~N} \\ \text { Northeast } & 93.502 \mathrm{~W} & 58.844 \mathrm{~N} \\ \text { Southeast } & 96.970 \mathrm{~W} & 50.089 \mathrm{~N} \\ \text { Southwest } & 111.000 \mathrm{~W} & 51.000 \mathrm{~N}\end{array}$

\subsubsection{Spatial Coverage Map}

Not available.

\subsubsection{Spatial Resolution}

These data were gridded to a cell size of 1,000 meters in the AEAC projection.

\subsubsection{Projection}

The area mapped is projected in the ellipsoidal version of the AEAC projection. The projection has the following parameters:

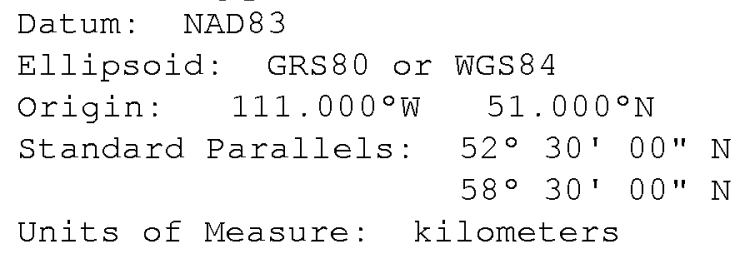

\subsubsection{Grid Description}

The data are gridded in 1,000-m intervals based on the ellipsoidal version of the AEAC projection with standard parallels of $52^{\circ} 30^{\prime} \mathrm{N}$ and $58^{\circ} 30^{\prime} \mathrm{N}$ and a lower left origin of $51^{\circ} \mathrm{N}$ and $111^{\circ} \mathrm{W}$. 


\subsection{Temporal Characteristics}

\subsubsection{Temporal Coverage}

The booklet that describes the original vector data set was published in 1991:

Soil Landscapes of Canada

Procedures Manual and User's Handbook

J.A. Shields, C. Tarnocai, K.W.G. Valentine, and K.B. MacDonald

Land Resource Research Centre

Ottawa, Ontario

\subsubsection{Temporal Coverage Map}

Not available.

\subsubsection{Temporal Resolution}

These data likely represent a compilation of soils information that was completed over a period of several years. BORIS views the data set as a single point reference source that can be used for soil and other studies. BORIS is not aware of any updates that have been made to the original data set.

\subsection{Data Characteristics}

The various gridded layers and the codes that describe their characteristics are listed under Section 7, Data Description.

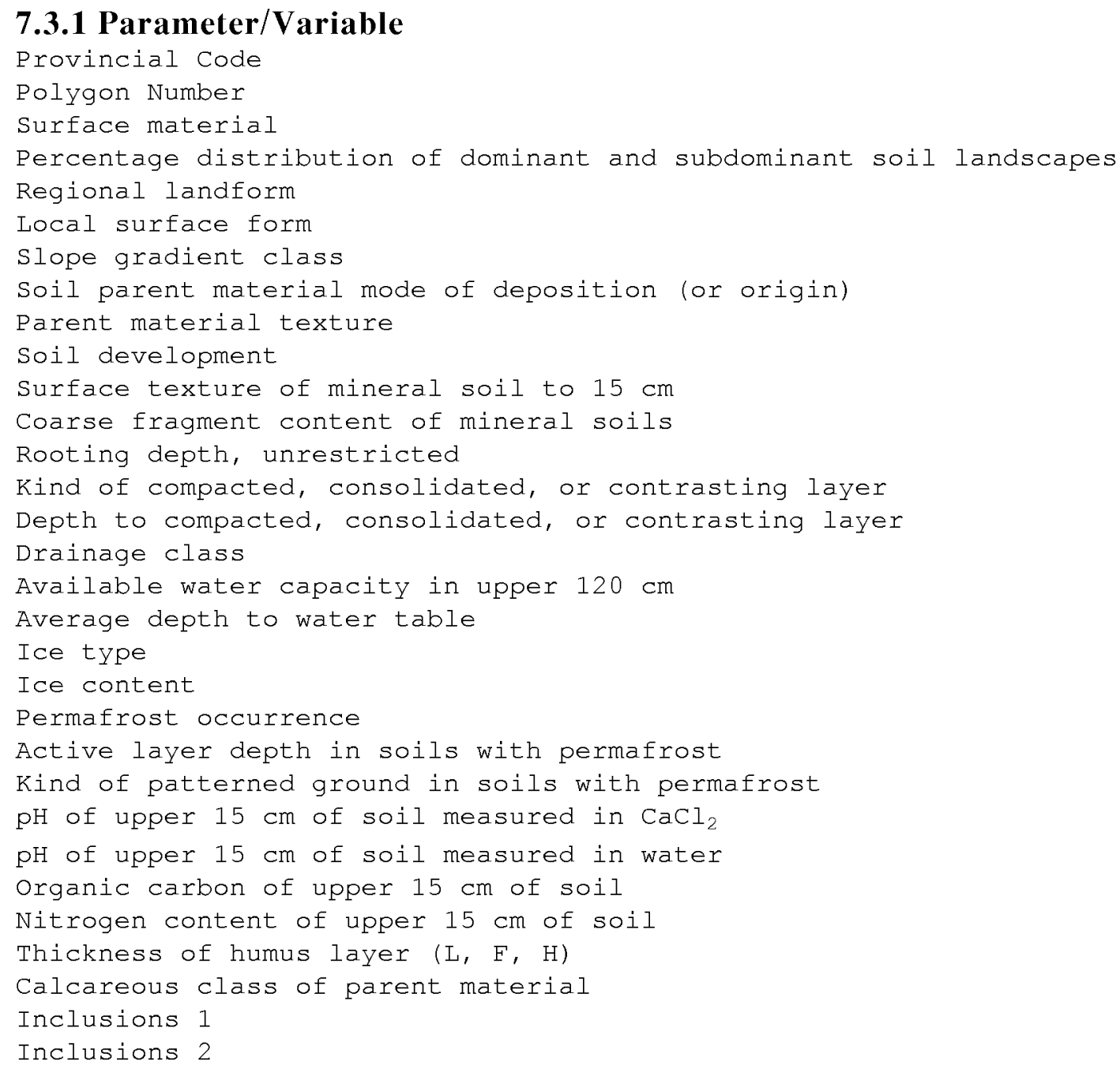




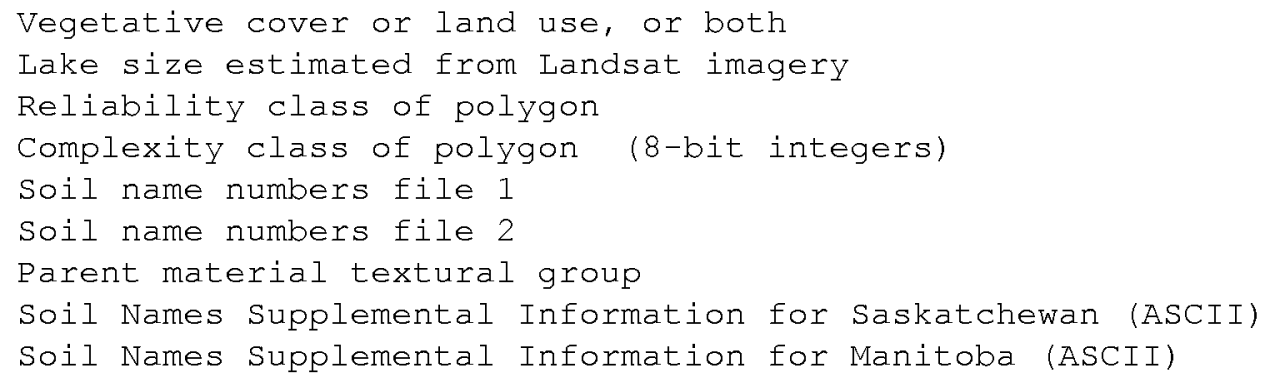

\subsubsection{Variable Description/Definition}

The following information was extracted (with modifications) from:

Soil Landscapes of Canada

Procedures Manual and User's Handbook

J.A. Shields, C. Tarnocai, K.W.G. Valentine, and K.B. MacDonald

Land Resource Research Centre

Ottawa, Ontario

\section{Provincial Code}

The value that designates whether the area is geographically located within Saskatchewan or Manitoba. In the provincial code file, the following values are used to represent Saskatchewan and Manitoba:

$\begin{array}{cl}\text { Pixel Value } & \text { Description } \\ ---------- & ------------ \\ 1 & \text { Saskatchewan } \\ 2 & \text { Manitoba }\end{array}$

\section{Polygon Number}

In the original data sets, the polygons composing the entire area were numbered 1 to $\mathrm{n}$. This value represents the polygon number from the original vector data and may not be useful to the user of this raster product.

\section{Surface material}

The type of material at the top of the soil in the area. In the dominant and subdominant surface material files, the following values are used to represent the various groupings:

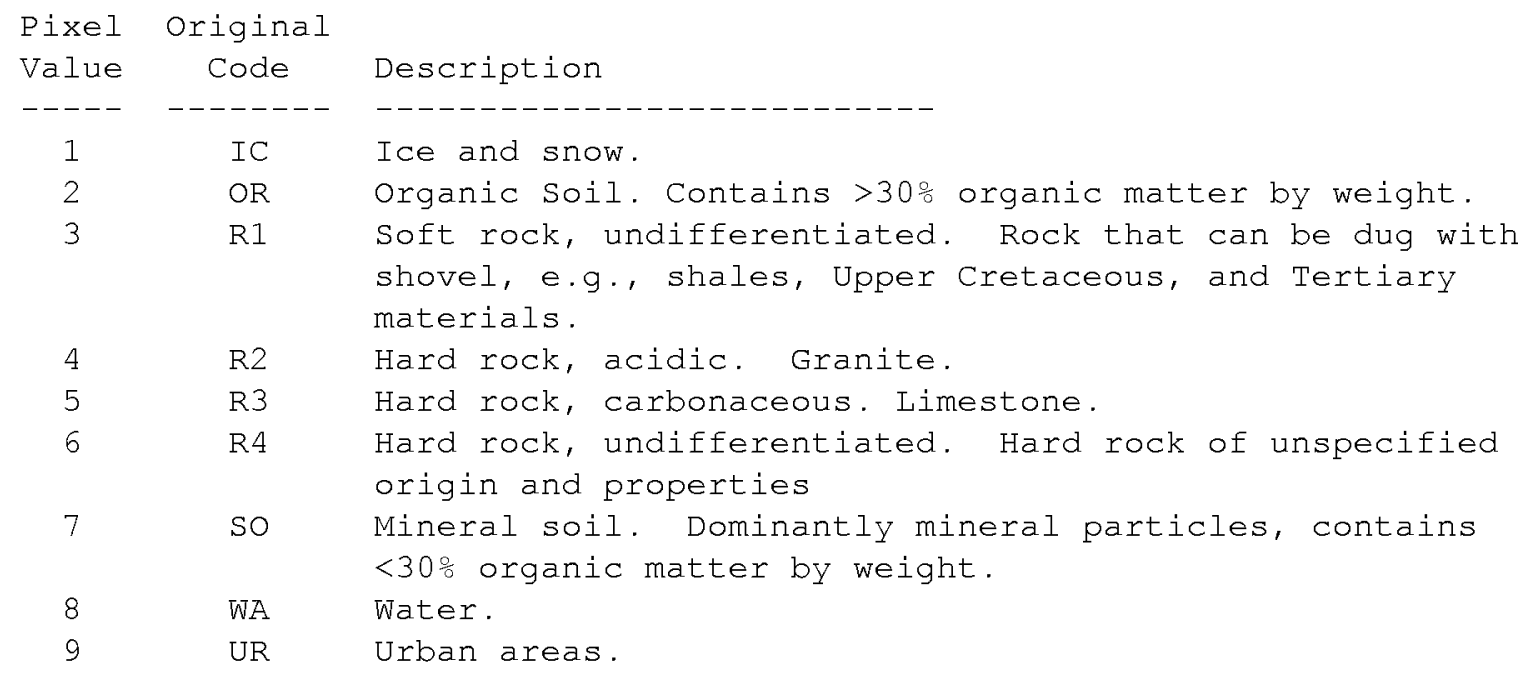


Note: Only a few major urban area polygons are shown on maps; do not use for tabulating urban areas.

$10 \quad$ \#ot applicable.

11 - Atribute does not occur.

Percentage distribution of dominant and subdominant soil landscapes: The values in the dominant and subdominant raster files represent the percentage of that soil landscape in the area.

\section{Regional landform}

The type of landform on which the area exists (e.g., mountain, hill, tableland). In the dominant and subdominant regional landform files, the following values are used to represent the various groupings:

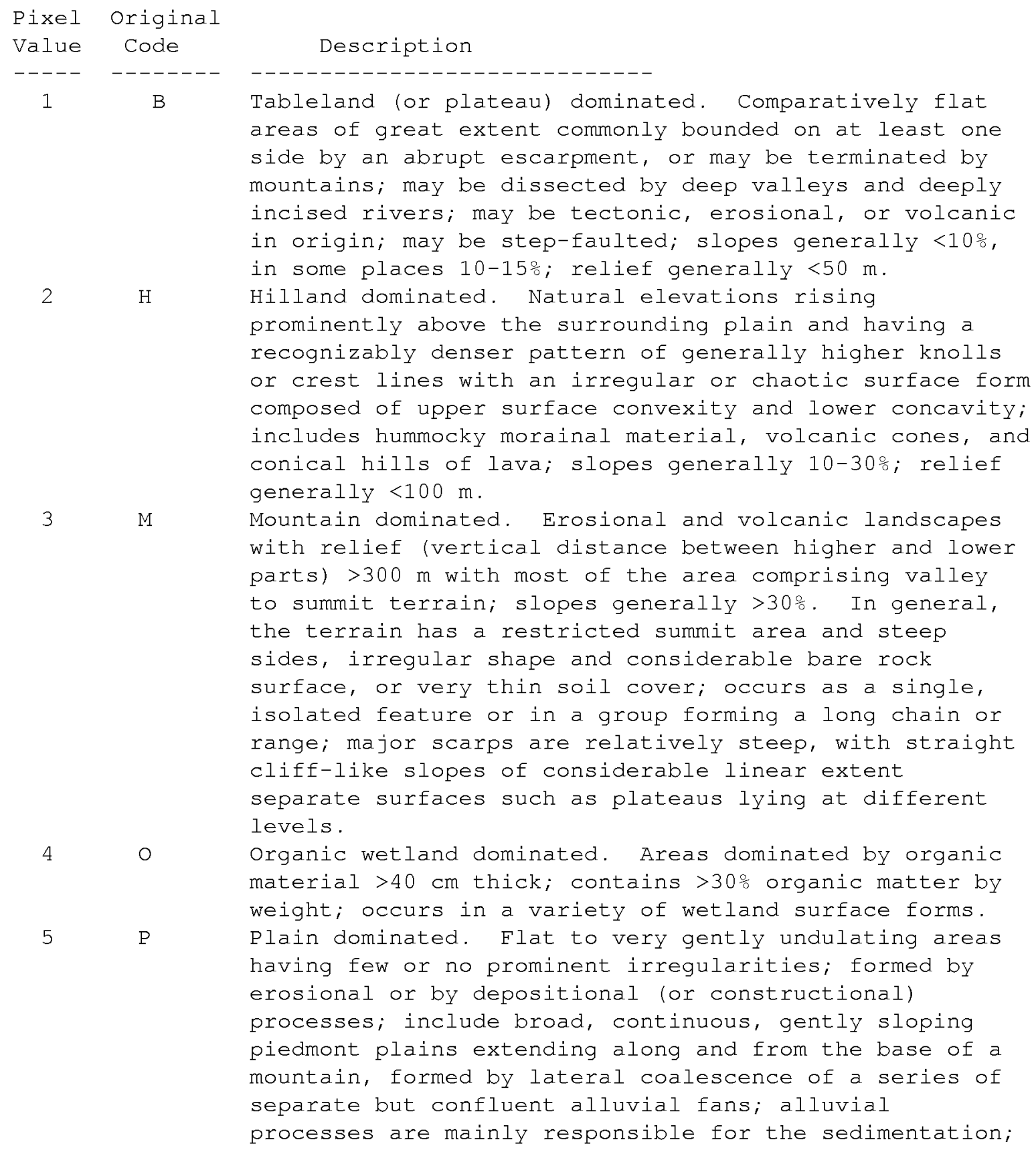




$\begin{array}{cl}6 \text { S } & \text { Scarp dominated. An escarpment, cliff, or steep slope } \\ & \text { of some extent along the margin of a terrace, bench, } \\ & \text { plateau, hill, or mesa; a scarp may be of any height. } \\ & \text { Valley dominated. Terrain dominated by major spillways, } \\ & \text { drainageways, or mountain trenches separated from } \\ & \text { surrounding landforms by a significant and abrupt break } \\ & \text { in slope; the valley profile may be V- or U-shaped with } \\ & \text { an extensive valley floor and flood plain up to about 5 } \\ & \text { km wide; valley profile may also include eroded } \\ & \text { terraces and their irregular slope segments. } \\ & \text { Not applicable (urban area, water, etc.). } \\ & \text { Attribute does not occur. }\end{array}$

\section{Local surface form}

The type of local surface form on which the area is located (e.g., inclined, level, dissected). In the dominant and subdominant local surface form files, the following values are used to represent the various groupings:






\begin{tabular}{|c|c|c|}
\hline 7 & $\mathrm{R}$ & $\begin{array}{l}\text { Ridged, A long, narrow elevation of the surface, usually } \\
\text { distinctly crested with steep sides; ridges may be parallel, } \\
\text { subparallel, or intersecting; examples: eskers, crevasse } \\
\text { fillings, washboard moraines, some drumlins. }\end{array}$ \\
\hline 8 & $S$ & $\begin{array}{l}\text { Steep. Erosional slopes }>70 \% \text {, on both consolidated and } \\
\text { unconsolidated materials; form of a steep erosional slope on } \\
\text { unconsolidated materials is not related to the initial mode } \\
\text { of origin of the underlying material; example: escarpments. }\end{array}$ \\
\hline 9 & $\mathrm{~T}$ & $\begin{array}{l}\text { Terraced. Scarp face and the horizontal or gently inclined } \\
\text { surface (or tread) above it; example: alluvial terrace. }\end{array}$ \\
\hline 10 & $\mathrm{U}$ & $\begin{array}{l}\text { Undulating. A very regular sequence of gentle slopes that } \\
\text { extends from rounded and, in some places, confined } \\
\text { concavities to broad, rounded convexities producing a } \\
\text { wavelike pattern of low local relief; slope length is } \\
\text { generally <0.8 km and the dominant gradient of slopes is } \\
\text { usually } 2-5 \% ; \text { it lacks an external drainage pattern; } \\
\text { examples: some ground moraine, lacustrine material of } \\
\text { varying texture. }\end{array}$ \\
\hline 11 & BO4 & $\begin{array}{l}\text { Domed bog. A large (diameter usually }>500 \mathrm{~m} \text { ) bog with a } \\
\text { convex surface, rising several meters above the surrounding } \\
\text { terrain; center usually drains in all directions; small } \\
\text { crescentic pools commonly form around the highest point; } \\
\text { if highest point is in the center, the pools form a } \\
\text { concentric pattern, or, if the highest point is off-center, } \\
\text { an eccentric pattern; the peat development is usually }>3 \mathrm{~m} \text {. }\end{array}$ \\
\hline 12 & BO5 & $\begin{array}{l}\text { Polygonal peat plateau bog. A perennially frozen bog, } \\
\text { rising about } 1 \mathrm{~m} \text { above the surrounding fen, the surface is } \\
\text { relatively flat, scored by a polygonal pattern of trenches } \\
\text { that developed over ice wedges; the permafrost and ice } \\
\text { wedges developed in peat originally deposited in a } \\
\text { nonpermafrost environment. }\end{array}$ \\
\hline 13 & BO 7 & $\begin{array}{l}\text { Peat plateau bog. A bog composed of perennially frozen } \\
\text { peat, rising abruptly about } 1 \mathrm{~m} \text { from the surrounding } \\
\text { unfrozen fen; the surface is relatively flat and even, } \\
\text { and commonly covers large areas; the peat was originally } \\
\text { deposited in a nonpermafrost environment and is associated } \\
\text { in many paces with collapse scar bogs or fens. }\end{array}$ \\
\hline 14 & BO9 & $\begin{array}{l}\text { Atlantic plateau bog. A bog with a flat-to-undulating } \\
\text { surface raised above the surrounding terrain, with the bog } \\
\text { edges commonly sloping steeply down toward the mineral soil } \\
\text { terrain; large pools scattered on the bog reach a depth of } \\
2-4 \mathrm{~m} \text {. }\end{array}$ \\
\hline 15 & B13 & $\begin{array}{l}\text { Basin bog. A bog situated in a basin that has an } \\
\text { essentially closed drainage, receiving water from } \\
\text { precipitation and from runoff from the immediate } \\
\text { surroundings; the surface of the bog is flat, but the peat } \\
\text { is generally deepest at the center. }\end{array}$ \\
\hline 16 & B14 & $\begin{array}{l}\text { Flat bog. A bog having a flat, featureless surface and } \\
\text { occurring in broad, poorly defined depressions; the depth of } \\
\text { peat is generally uniform. }\end{array}$ \\
\hline 17 & B1 5 & $\begin{array}{l}\text { String bog. A pattern of narrow }(2-3 \mathrm{~m} \text { wide), low }(<1 \mathrm{~m} \\
\text { deep) ridges oriented at right angles to the direction of } \\
\text { drainage; wet depressions or pools occur between the ridges; } \\
\text { the water and peat are very low in nutrients because the }\end{array}$ \\
\hline
\end{tabular}

Page 12 
water has been derived from other ombrotrophic wetlands; peat thickness $>1 \mathrm{~m}$.

18 B16 Blanket bog. A bog consisting of extensive peat deposits that occur more or less uniformly over gently sloping hills and valleys; the peat thickness is usually $<2 \mathrm{~m}$.

19 B18 Slope bog. A bog occurring in areas of high rainfall on appreciably sloping land surfaces, fed by rainwater and by water draining from other nutrient-poor wetlands; the peat may exceed $1 \mathrm{~m}$ in thickness.

20 B19 Veneer bog. A bog occurring on gently sloping terrain underlain by generally discontinuous permafrost; although drainage is predominantly below the surface, overland flow occurs in poorly defined drainageways during peak runoff; peat thickness is usually $<1.5 \mathrm{~m}$.

$21 \quad$ FO1

Northern ribbed fen. A fen with parallel, low peat ridges ("strings") alternating with wet hollows or shallow pools, oriented across the major slope at right angles to water movement; the depth of peat is $>1 \mathrm{~m}$.

22 FO7 Shore fen. A fen with an anchored surface mat that forms the shore of a pond or lake; the rooting zone is affected by the water of the lake at both normal and flood levels.

23 F11 Slope fen. A fen occurring mainly on slow-drainage, nutrient-enriched seepage slopes; pools are usually absent, but wet seepage tracks may occur; peat thickness is usually $<2 \mathrm{~m}$.

24 F13 Horizontal fen. A fen with a very gently sloping, featureless surface; this fen occupies broad, often illdefined depressions and may interconnect with other fens; peat accumulation is generally uniform.

Stream swamp. A swamp occurring along the banks of permanent or semipermanent streams; the high-water table is maintained by the level of water in the stream; the swamp is seasonally inundated, with subsequent sediment deposition. Basin swamp. A swamp developed in a topographically defined basin where water derived locally may be augmented by drainage from other parts of the watershed; accumulation of well-decomposed peat is shallow $(<0.5 \mathrm{~m})$ at the edge and may reach $2 \mathrm{~m}$ at the center.

Stream marsh. A marsh occupying shorelines, bars, streambeds, or islands in continuously flowing water courses; the marsh is subject to prolonged annual flooding and is commonly covered by thick layers of sediments. shallow basin marsh. A marsh occurring in a uniformly shallow depression or swale, having a gradual gradient from the edge to the deepest portion; the marsh edge may be poorly defined; water levels fluctuate rapidly.

29 M14 Shore marsh. A marsh occupying the contact zone between high and low water marks bordering semipermanent or permanent lakes; the marsh is usually found along protected shorelines, in lagoons behind barrier beaches, on islands, or in embayments; the marsh is subject to flooding by rise in lake levels, wind, waves, or surface runoff. Not applicable (urban area, water, etc.). Attribute does not occur.

\section{Page 13}




\section{Slope gradient class}

The slope category of the land surface area. In the dominant and subdominant slope gradient class files, the following values are used to represent the various groupings:

\begin{tabular}{ccc} 
Pixel & Original \\
Value & Code & \multicolumn{1}{c}{ Description } \\
---- & ------ & -------------------- \\
1 & A & $1-3 \%$ (includes slopes <1\%) \\
2 & B & $4-9 \%$ \\
3 & $\mathrm{C}$ & $10-15 \%$ \\
4 & $\mathrm{D}$ & $16-30 \%$ \\
5 & $\mathrm{E}$ & $31-60 \%$ \\
6 & $\mathrm{~F}$ & $>60 \%$ \\
7 & $\#$ & Not applicable (water) \\
8 & - & Attribute does not occur
\end{tabular}

\section{Soil parent material mode of deposition (or origin)}

The mode in which the soil parent material was deposited on the area (e.g., colluvial, eolian, bog). In the dominant and subdominant soil parent material files, the following values are used to represent the various groupings:

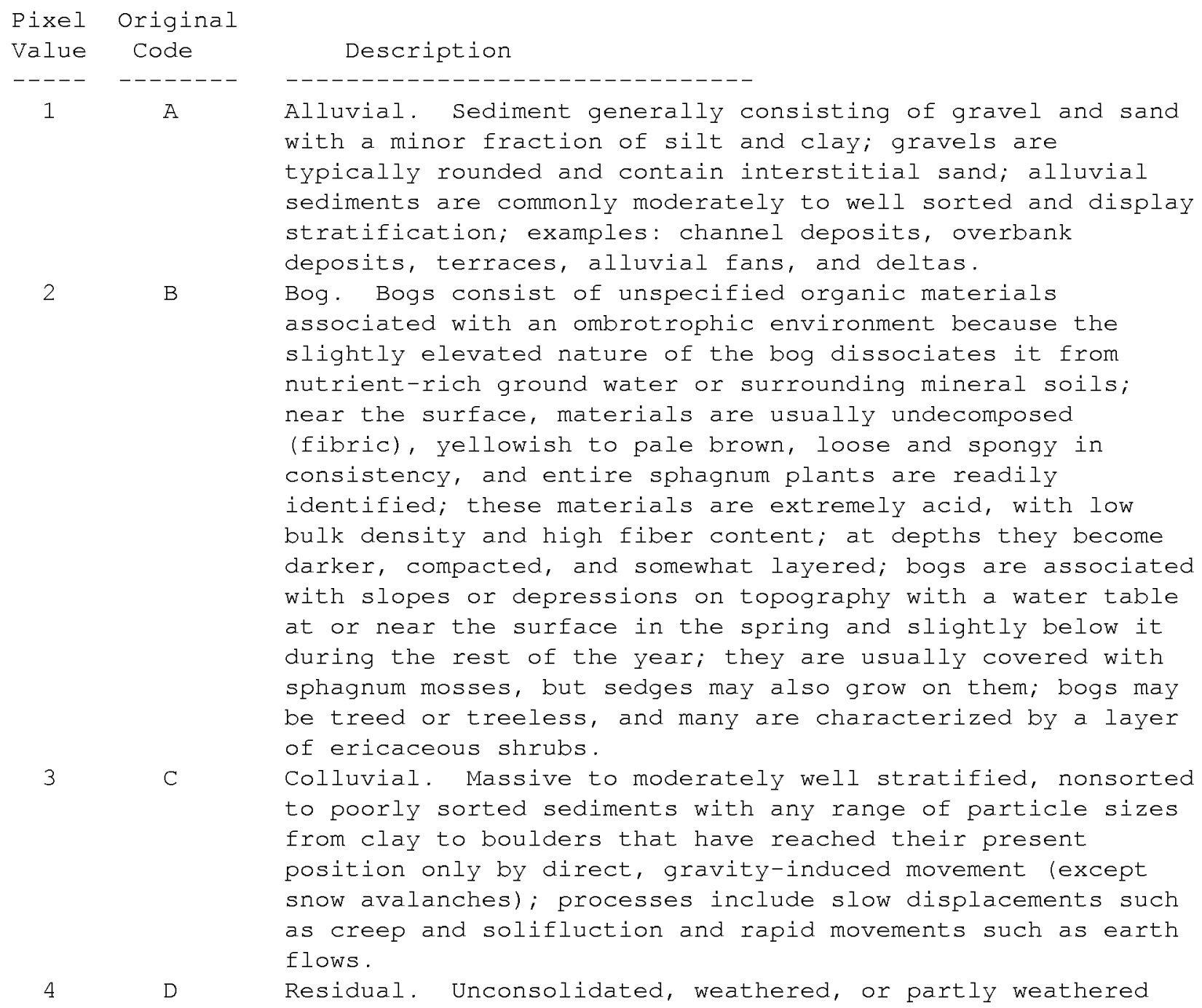


soil mineral material that accumulates by disintegration of bedrock in place.

Eolian. Sediment, generally consisting of medium-to-fine sand and coarse silt particle sizes, that is well sorted, poorly compacted, and may show internal structures such as cross bedding or ripple laminae, or may be massive; individual grains may be rounded and show signs of frosting; these materials have been transported and deposited by wind action; examples: dunes, shallow deposits and sand and coarse silt, and loess but not tuffs.

Fluvioglacial. Material moved by glaciers and subsequently sorted and deposited by streams flowing from the melting ice; deposits are stratified and may occur in the form of outwash plains, deltas, kames, eskers, and kame terraces. Marsh. Mineral wetland or wetland that is periodically inundated by standing or slow-moving water; surface water levels may fluctuate seasonally, with declining levels exposing drawdown zones of matted vegetation or mudflats; waters are rich in nutrients, varying from fresh to highly saline; substratum usually consists of mineral material, although in some places it consists of well-decomposed peat; soils are predominantly Gleysols, with some Humisols and Mesisols; marshes characteristically show zonal or mosaic surface patterns composed of pools or channels interspersed with clumps of emergent sedges, grasses, rushes, and reeds, bordering grassy meadows, and peripheral bands of shrubs or trees; submerged and floating aquatics flourish where openwater areas occur.

Lacustrine. Sediment generally consisting of either stratified fine sand, silt, and clay deposited on the lake bed or moderately well-sorted and stratified sand and coarser materials that are beach and other nearshore sediments transported and deposited by wave action; these materials either have settled from suspension in bodies of standing freshwater or have accumulated at their margins through wave action; examples: lake sediments and beaches. Morainal. Sediment generally consisting of well-compacted material that is nonstratified and contains a heterogeneous mixture of sand, silt, and clay particle sizes and coarse fragments in a mixture that has been transported beneath, beside, on, within, or in front of a glacier and not modified by any intermediate agent; examples: basal till (ground moraines, rubbly moraines of cirque glaciers, hummocky ice-disintegration moraines, and pre-existing, unconsolidated sediments reworked by a glacier so that their original character is largely or completely destroyed.

Fen. Fen consists of unspecified organic materials formed in a minerotrophic environment because of the close association of the material with mineral-rich waters; it is usually moderately well to well decomposed, dark brown to black, with fine- to medium-sized fibers; decomposition commonly becomes greater at lower depths; the materials are covered with a dominant component of sedges, but grasses and reeds may be associated in local pools.

\section{Page 15}


11

Organic, undifferentiated. A layered sequence of more than three types of organic material ( $>30 \%$ organic matter by weight).

Rock. A consolidated bedrock layer that is too hard to break with the hands ( $>3$ on Mohs' scale) or to dig with a spade when moist.

Swamp. Minerotrophic wetlands with the water table at or above the peat surface; dominant unspecified organic materials are forest and fen peat formed in a eutrophic environment because of strong water movement from the margins or other mineral sources; it is usually moderately well to well decomposed and has a dark brown to reddish brown matrix; the more decomposed materials are black; it has an amorphous or very fine-fibered structure containing a random distribution of woody fragments and trunks of coniferous tree species; the vegetation cover may consist of coniferous or deciduous trees, tall shrubs, herbs, and mosses; in some regions sphagnum mosses are abundant. Anthropogenic. Materials modified by people, including those associated with mineral exploitation and waste disposal; they include materials deposited as a result of human activities or geological materials modified artificially so that their physical properties (structure, cohesion, compaction) have been drastically altered; examples: areas of landfill, spoil heaps, open-pit mines, leveled irrigated areas.

Undifferentiated. A sequence of more than three types of genetic mineral materials outcropping on a steep erosional escarpment; this complex class is to be used where units relating to individual genetic materials cannot be delimited separately at the scale of mapping; it may include colluvium derived from the various genetic materials and resting upon the scarp slope.

Volcanic. Volcanic pumice and ash.

Marine. Unconsolidated deposits of clay, silt, sand, or gravel that are well to moderately well sorted and well to moderately well stratified (in some places containing shells); they have settled from suspension in salt or brackish water bodies or have accumulated at their margins through shoreline processes such as wave action and longshore drift; nonfossiliferous deposits may be judged marine, if they are located in an area that might reasonably be considered to have contained saltwater at the time the deposits were formed.

Fibric Sphagnum. Sphagnum organic material in a fibric degree of decomposition in which the fibric materials are readily identifiable as to botanical origin; peat is usually undecomposed (or fibric), light yellowish brown to pale brown, and loose and spongy in consistency with the entire sphagnum plant being readily identifiable.

Mesic sedge. Sedge organic material in a mesic (or intermediate) degree of decomposition; peat composed dominant $l_{Y}$ of sedge (Carex spp.) and generall $l_{Y}$ moderately decomposed and matted; the sedge leaves are readily 
identifiable to the naked eye; this material commonly contains large amounts of very fine roots of the above species.

\begin{tabular}{|c|c|c|}
\hline 20 & 22 & $\begin{array}{l}\text { Mesic woody sedge. Woody sedge organic material in a mesic } \\
\text { (or intermediate) degree of decomposition; peat is composed } \\
\text { dominantly of sedge peat (see code 21) with subdominant } \\
\text { amounts of woody materials. }\end{array}$ \\
\hline 21 & 23 & $\begin{array}{l}\text { Mesic woody forest. Woody forest organic material in a } \\
\text { mesic (or intermediate) degree of decomposition; peat is } \\
\text { composed dominantly (>50\%) of woody materials derived from } \\
\text { both coniferous and deciduous tree species; in general, } \\
\text { wood fragments are easily identifiable in this peat. }\end{array}$ \\
\hline & 25 & $\begin{array}{l}\text { Mesic sphagnum. Sphagnum organic material in a mesic (or } \\
\text { intermediate) degree of decomposition. }\end{array}$ \\
\hline & 31 & $\begin{array}{l}\text { Humic sedge. Sedge organic material in a humic (or most } \\
\text { advanced) degree of decomposition in which most of the } \\
\text { material is humified, and there are few recognizable } \\
\text { fibers. }\end{array}$ \\
\hline & $\#$ & Not applicable (urban area, water, etc.). \\
\hline & & Attribute does not occur. \\
\hline
\end{tabular}

\section{Parent material texture}

The texture category to which the parent material was assigned (e.g., very fine sand, sandy loam, clay). In the dominant and subdominant soil parent material texture files, the following values are used to represent the various groupings:

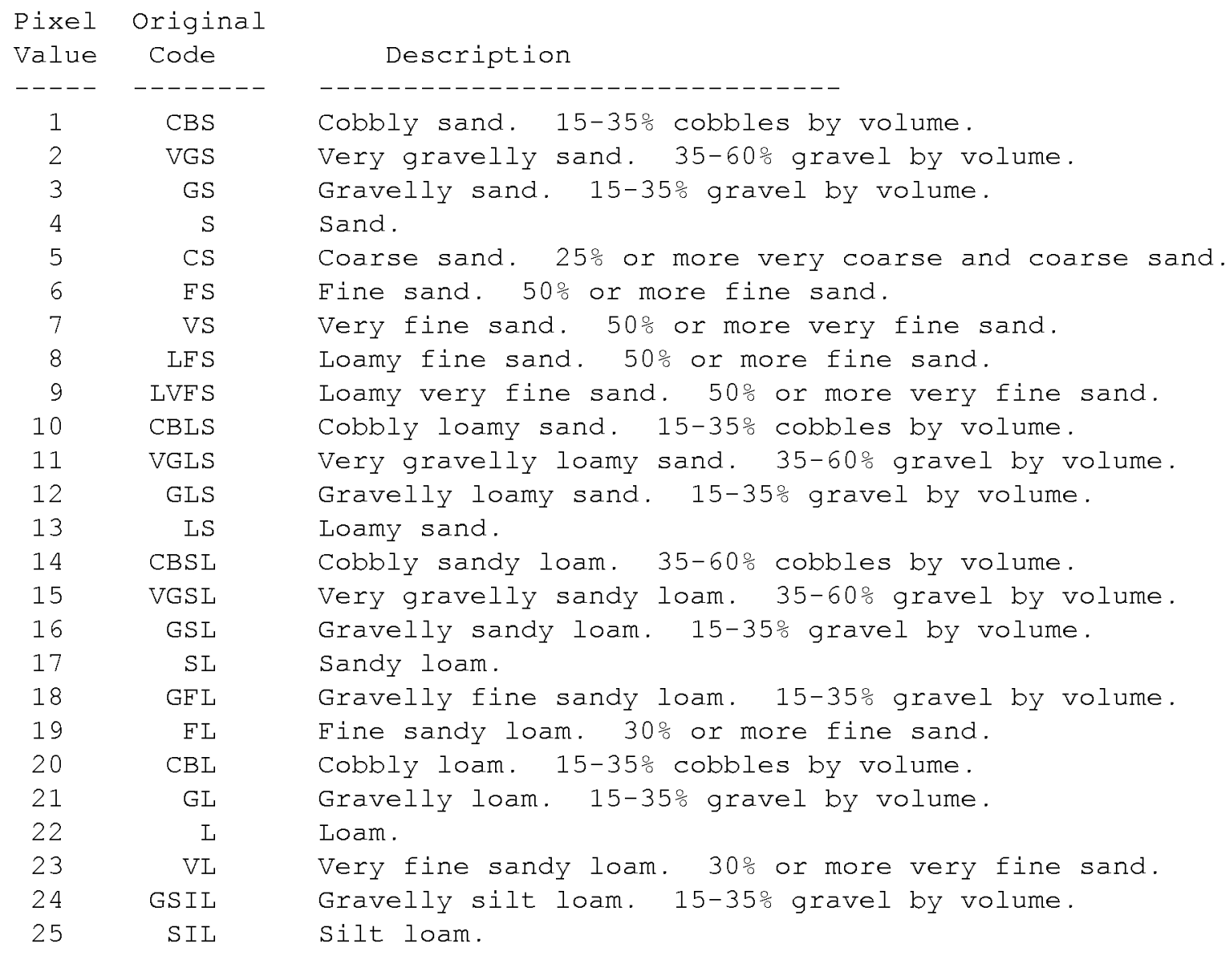




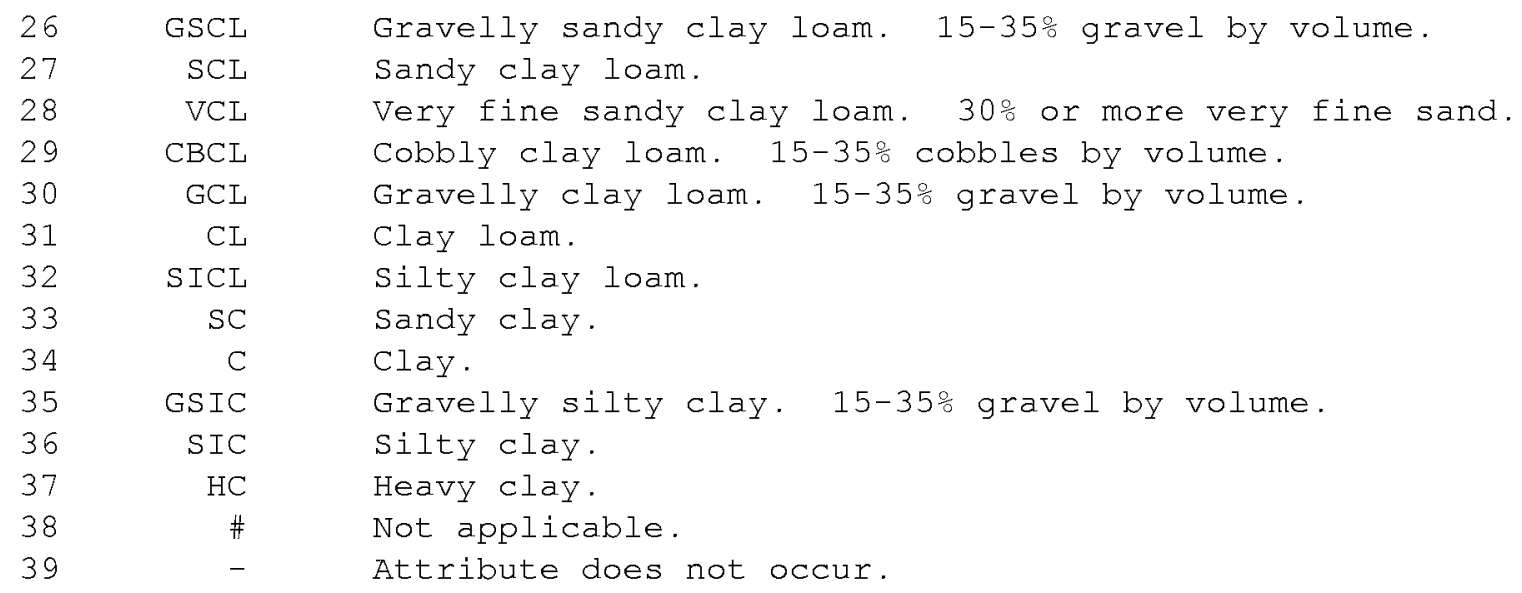

\section{Soil development}

The category of soil development for the area (e.g., Gray Brown Luvisolic, Eutric Brunisolic). In the dominant and subdominant soil development files, the following values are used to represent the various groupings:

\begin{tabular}{|c|c|}
\hline $\begin{array}{l}\text { Pixel } \\
\text { Value }\end{array}$ & $\begin{array}{l}\text { Original } \\
\text { Code }\end{array}$ \\
\hline----- & -------- \\
\hline 1 & A \\
\hline 2 & B \\
\hline 3 & $\mathrm{C}$ \\
\hline 4 & $\mathrm{D}$ \\
\hline 5 & $\mathrm{E}$ \\
\hline 6 & $\mathrm{~F}$ \\
\hline 7 & $\mathrm{G}$ \\
\hline 8 & $\mathrm{H}$ \\
\hline 9 & $I$ \\
\hline 10 & $\mathrm{~J}$ \\
\hline 11 & $\mathrm{~K}$ \\
\hline
\end{tabular}

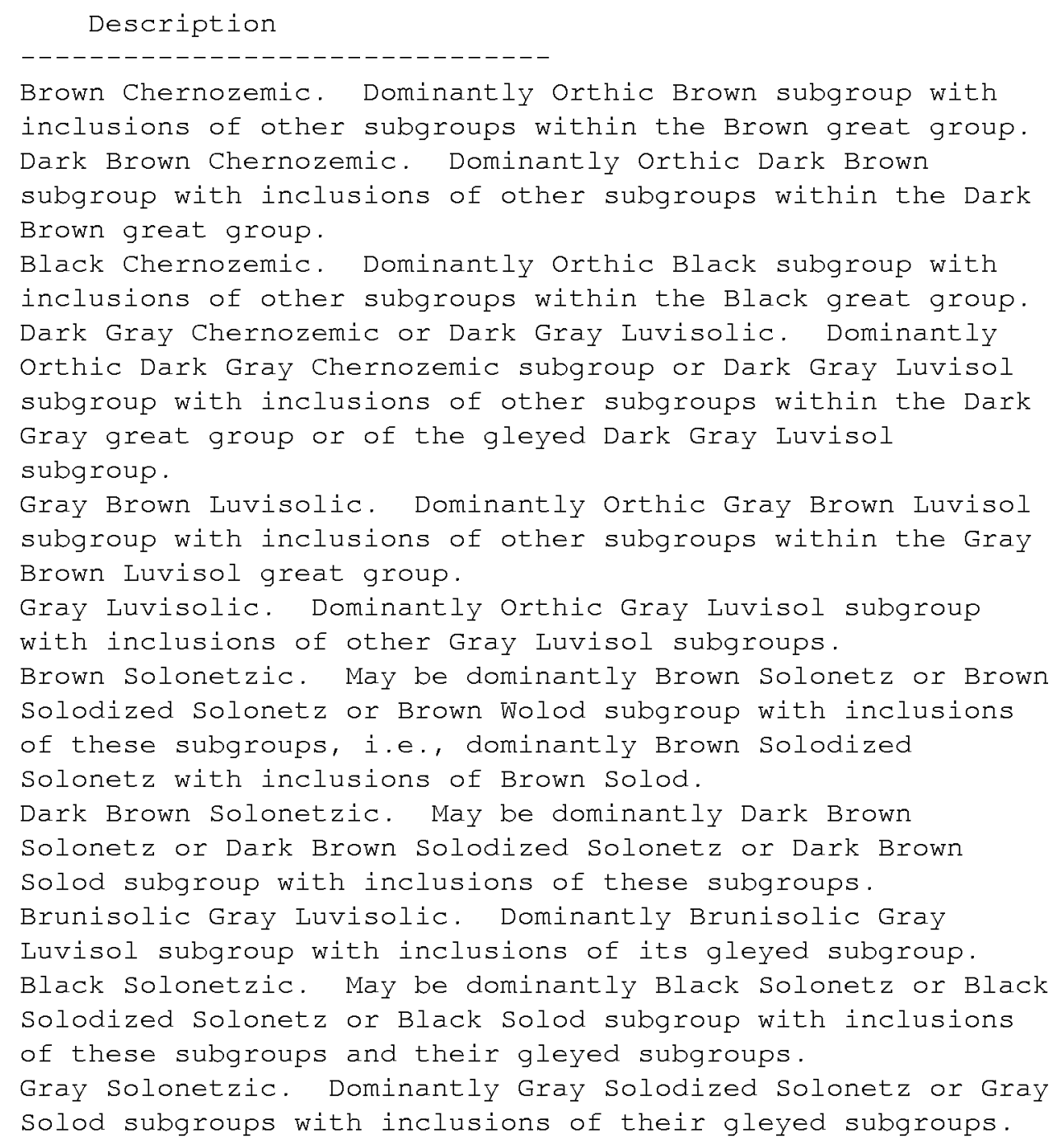




\begin{tabular}{|c|c|c|}
\hline 12 & L & $\begin{array}{l}\text { Melanic Brunisolic. Dominantly Melanic Brunisol great } \\
\text { group. }\end{array}$ \\
\hline 13 & M & Dominantly Eutric Brunisol great group. \\
\hline 14 & $\mathrm{~N}$ & $\begin{array}{l}\text { Sombric Brunisolic. Dominantly Sombric Brunisol great } \\
\text { group. }\end{array}$ \\
\hline 15 & $\mathrm{O}$ & Dominantly Organic Cryosol great group. \\
\hline 16 & $\mathrm{P}$ & $\begin{array}{l}\text { Dystric Brunisolic. Dominantly Dystric Brunisol great } \\
\text { group. }\end{array}$ \\
\hline 17 & $Q$ & Humic Podzolic. Dominantly Humic Podzol great group. \\
\hline 18 & $\mathrm{R}$ & Regosolic. Dominantly Regosolic order. \\
\hline 19 & $S$ & Static Cryosolic. Dominantly static Cryosol great group. \\
\hline 20 & $\mathrm{~T}$ & Turbic Cryosolic. Dominantly Turbic Cryosol great group. \\
\hline 21 & $\mathrm{U}$ & Gleysolic. Dominantly Gleysolic order. \\
\hline 22 & $\mathrm{~V}$ & $\begin{array}{l}\text { Ferro-Humic Podzolic. Dominantly Ferro-Humic Podzol great } \\
\text { group. }\end{array}$ \\
\hline 23 & W & $\begin{array}{l}\text { Humo-Ferric Podzolic. Dominantly Humo-Ferric Podzol great } \\
\text { group. }\end{array}$ \\
\hline 24 & $\mathrm{X}$ & Fibrisol. Dominantly Fibrisol great group. \\
\hline 25 & Y & Mesisol. Dominantly Mesisol great group \\
\hline 26 & Z & Humisol. Dominantly Humisol great group. \\
\hline 27 & 2 & Folisol. Dominantly Folisol great group. \\
\hline 28 & 3 & $\begin{array}{l}\text { Podzolic Gray. Podzolic Gray Luvisol subgroup; only occurs } \\
\text { as subdominant. }\end{array}$ \\
\hline 29 & $\#$ & Not applicable (water, rock, or ice) \\
\hline 30 & - & Attribute does not occur. \\
\hline
\end{tabular}

\section{Surface texture of mineral soil to $15 \mathrm{~cm}$}

The texture of the soil between the surface and a depth of $15 \mathrm{~cm}$. The values and codes shown above for parent material texture also apply to the surface soil texture.

\section{Coarse fragment content of mineral soils}

The categorized percent by volume of rounded, subrounded, flat, angular, or irregular rock fragment from 0.2 to $60 \mathrm{~cm}$ or more in size. In the dominant and subdominant coarse fragment content files, the following values are used to represent the various groupings:

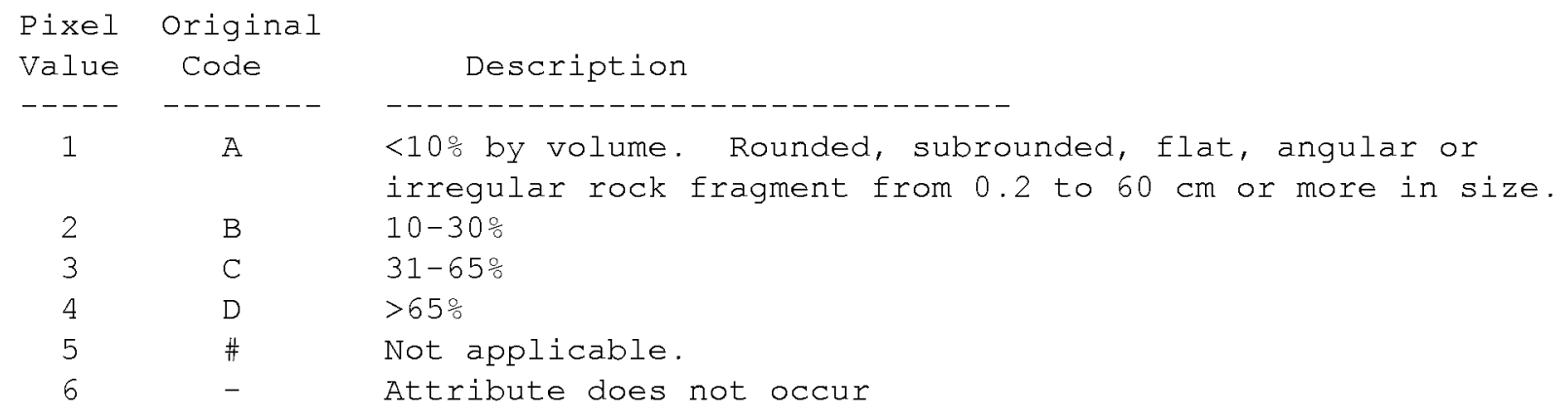




\section{Rooting depth, unrestricted}

The unrestricted rooting depth for vegetation that is growing in the area. In the dominant and subdominant rooting depth files, the following values are used to represent the various groupings:

\begin{tabular}{ccl} 
Pixel & Original & \\
Value & Code & \multicolumn{1}{c}{ Description } \\
---- & ------- & --------------------- \\
1 & 0 & $<20 \mathrm{~cm}$ \\
2 & 50 & $20-75 \mathrm{~cm}$ \\
3 & 100 & $76-150 \mathrm{~cm}$ \\
4 & 200 & $>150 \mathrm{~cm}$ \\
5 & $\#$ & Not applicable (e.g., rock, ice) \\
6 & - & Attribute does not occur
\end{tabular}

\section{Kind of compacted, consolidated, or contrasting layer}

The type of compacted, consolidated, or contrasting layer that is present (e.g., Ortstein). In the dominant and subdominant compacted, consolidated, or contrasting layer files, the following values are used to represent the various groupings:

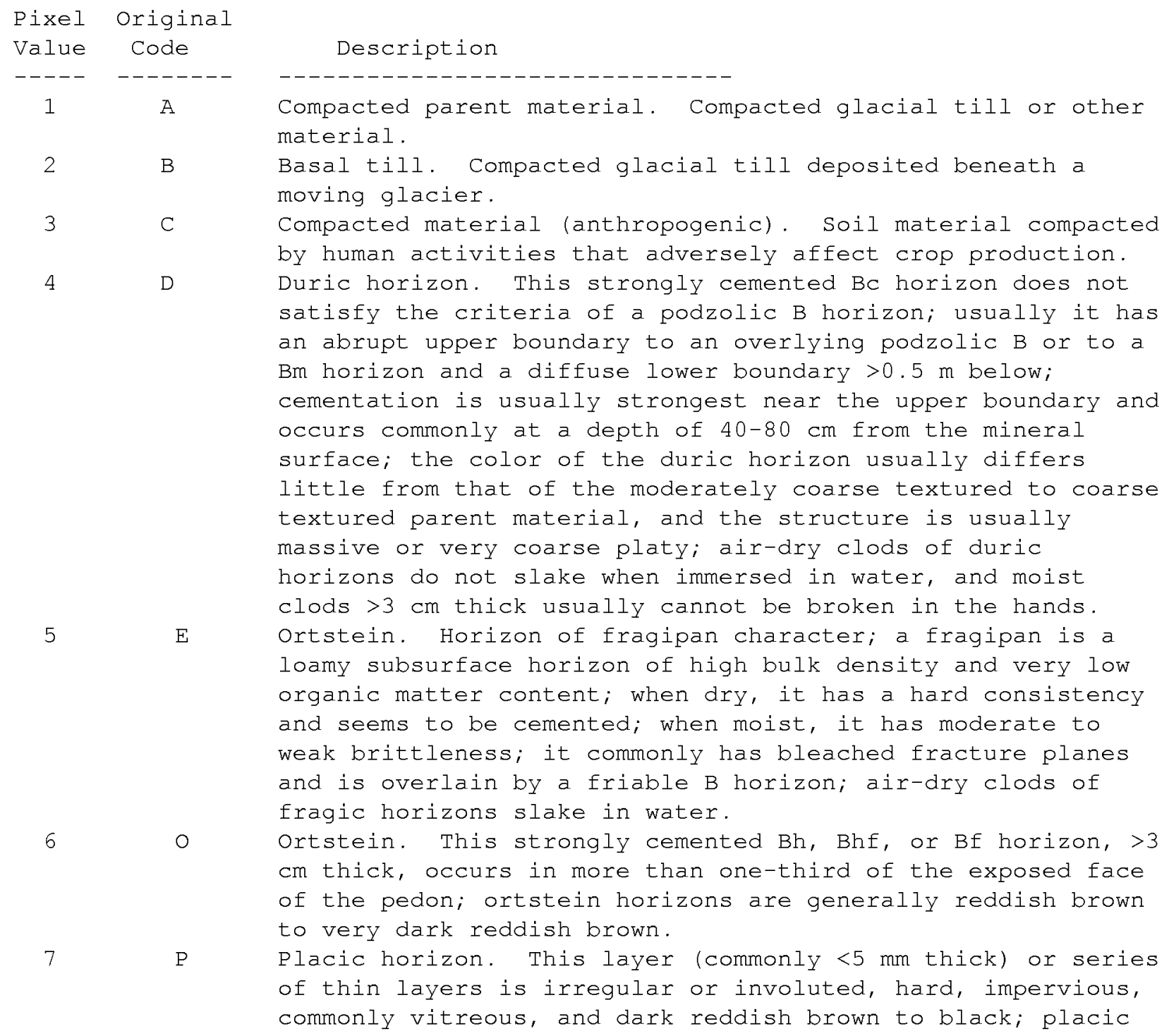


horizons may be cemented by Fe, Al-organic complexes (Bhfc or Bfc), hydrated Fe oxides (Bgfc) or a mixture of Fe and Mn oxides.

\begin{tabular}{|c|c|c|}
\hline 8 & $\mathrm{R}$ & $\begin{array}{l}\text { Rock. Consolidated bedrock too hard either to break with } \\
\text { the hands ( }>3 \text { on Mohs' scale) or to dig when moist. }\end{array}$ \\
\hline 9 & G & $\begin{array}{l}\text { Gravel. A layer of coarse fragments with diameters of } \\
0.2-7.5 \mathrm{~cm} \text {. }\end{array}$ \\
\hline 10 & $\mathrm{~L}$ & Colluvium. See attribute number 09, code C. \\
\hline 11 & $S$ & $\begin{array}{l}\text { Sand. Soil texture class in which the material contains } \\
>85 \% \text { of sand-sized separate; the percentage of silt plus } 1.5 \\
\text { times the percentage of clay does not exceed } 15 \% \text {. }\end{array}$ \\
\hline 12 & $\mathrm{X}$ & $\begin{array}{l}\text { Silt. Soil texture class in which the material contains } \\
>80 \% \text { silt and }<12 \% \text { clay. }\end{array}$ \\
\hline 13 & Y & $\begin{array}{l}\text { Clay. Soil texture class in which the material contains } \\
>40 \% \text { clay, }<45 \% \text { sand, and }<40 \% \text { silt-sized separates. }\end{array}$ \\
\hline 14 & $\#$ & Not applicable. \\
\hline & - & Attribute does not occur. \\
\hline
\end{tabular}

\section{Depth to compacted, consolidated, or contrasting layer}

The depth class for any compacted, consolidated, or contrasting layer that exists. In the dominant and subdominant depth to compacted, consolidated, or contrasting layer files, the following values are used to represent the various groupings:

\begin{tabular}{ccl} 
Pixel & Original \\
Value & Code & \multicolumn{1}{c}{ Description } \\
---- & ------- & ------------- \\
1 & 1 & $0-49 \mathrm{~cm}$ \\
2 & 2 & $50-100 \mathrm{~cm}$ \\
3 & 3 & $>100 \mathrm{~cm}$ \\
4 & 4 & $<100 \mathrm{~cm}$ for mineral overlays \\
5 & 5 & $<160 \mathrm{~cm}$ for shale (terric) organic \\
6 & $\#$ & Not applicable \\
7 & - & Attribute does not occur
\end{tabular}

\section{Drainage class}

The drainage class of the soil over the area (e.g., excessive, rapid, poor). In the dominant and subdominant drainage class files, the following values are used to represent the various groupings:

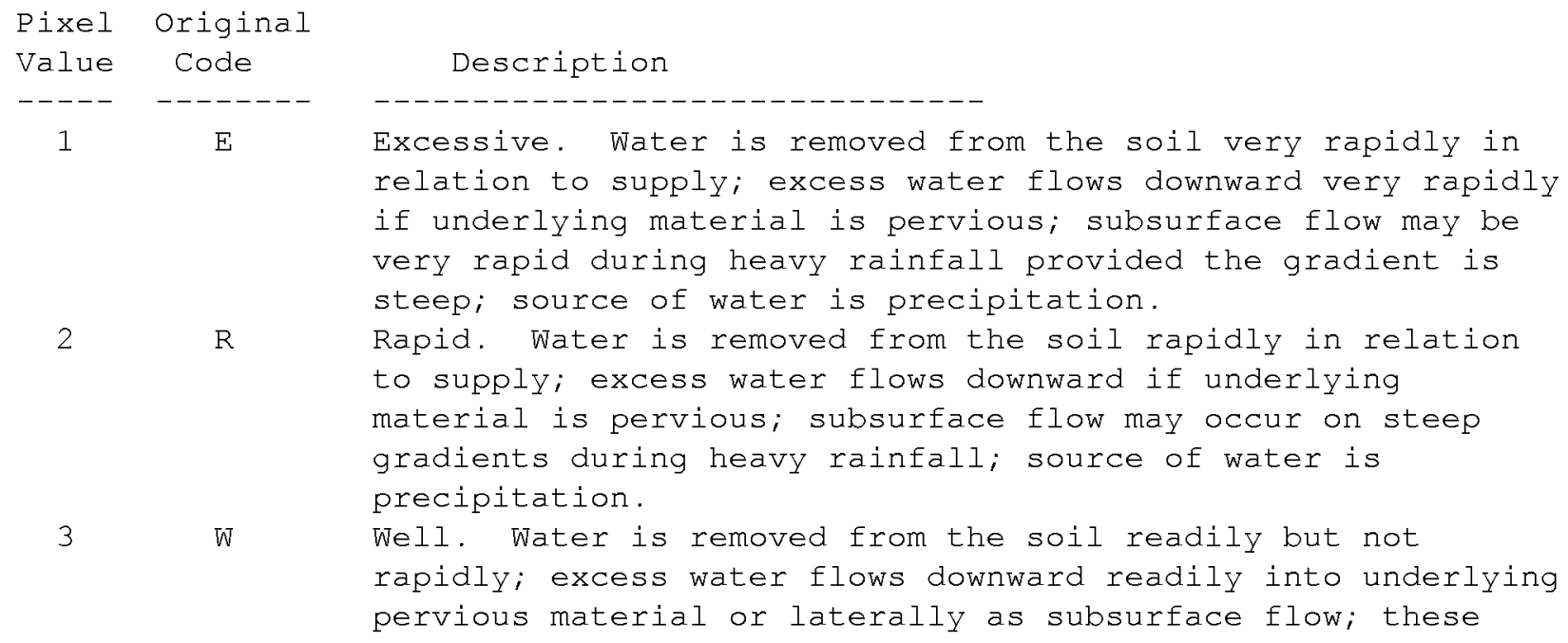


soils commonly retain optimum amounts of moisture for plant growth after rains or addition of irrigation water.

$4 \quad \mathrm{M}$

Moderately well. Water is removed from the soil somewhat slowly in relation to supply; excess water is removed somewhat slowly because of low perviousness, shallow water table, lack of gradient, or some combination of these; precipitation is the dominant source of water in medium-tofine textured soils; precipitation and significant additions by subsurface flow are necessary in coarse-textured soils.

Imperfect. Water is removed from the soil sufficiently slowly in relation to supply to keep the soil wet for a significant part of the growing season; excess water moves slowly downward if precipitation is the major supply; if subsurface water or groundwater, or both, is the main source, the flow rate may vary, but the soil remains wet for a significant part of the growing season.

Poor. Water is removed so slowly in relation to supply that the soil remains wet for a comparatively large part of the time the soil is not frozen; excess water is evident in the soil for much of the time; subsurface flow or groundwater flow, or both, in addition to precipitation are the main sources of water; there may also be a perched water table. Very poor. Water is removed from the soil so slowly that the water table remains at or on the surface for most of the time the soil is not frozen; groundwater flow and subsurface flow are the major sources of water; precipitation is less important except where there is a perched water table.

8 \# Not applicable.

9 - Attribute does not occur.

\section{Available water capacity in upper $120 \mathrm{~cm}$}

That portion of water in a soil that can be readily absorbed by plant roots; generally considered to be the water held in the soil between field capacity and a pressure of up to about 15 bars. In the dominant and subdominant water capacity files, the following values are used to represent the various groupings:

$\begin{array}{cc}\text { Pixel } & \text { Original } \\ \text { Value } & \text { Code } \\ ---- & ------ \\ 1 & 1 \\ 2 & 2 \\ 3 & 3 \\ 4 & 4 \\ 5 & 5 \\ 6 & 6 \\ 7 & 7 \\ 8 & 8 \\ 9 & \# \\ 10 & -\end{array}$

Description
50 mm
$100 \mathrm{~mm}$
$150 \mathrm{~mm}$
$200 \mathrm{~mm}$
$250 \mathrm{~mm}$
Not applicable (solonetzic or saline soils)
Not applicable (high water table)
Not applicable (perennially frozen subsoils)
Not applicable (water, ice, rock)
Attribute does not occur

Page 22 


\section{Average depth to water table}

The average depth to the water table in the area. In the dominant and subdominant depth to water table files, the following values are used to represent the various groupings:

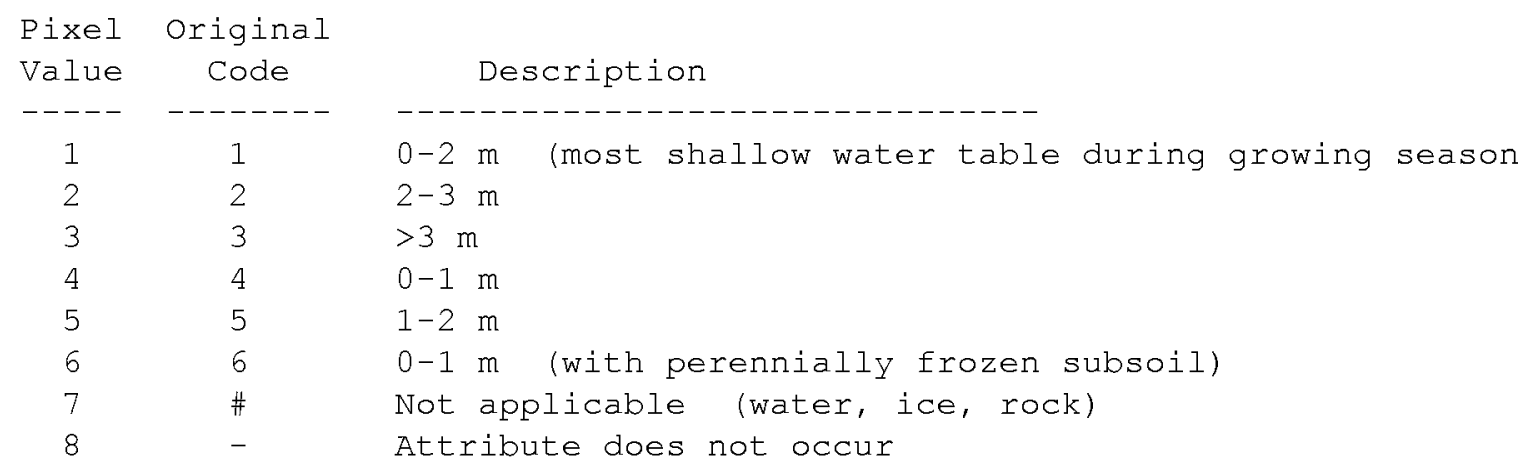

\section{Ice type}

The type of ice found in the soil. In the dominant and subdominant ice type files, the following values are used to represent the various groupings:

\begin{tabular}{ccl}
$\begin{array}{c}\text { Pixel } \\
\text { Value }\end{array}$ & $\begin{array}{c}\text { Original } \\
\text { Code }\end{array}$ & \multicolumn{1}{c}{ Description } \\
---- & ------- & ----------------------- \\
1 & 1 & Ice crystals and ice lenses \\
2 & 2 & Ice wedges \\
3 & 3 & Massive ground ice \\
4 & 4 & Undifferentiated \\
5 & $\#$ & Not applicable \\
6 & - & Attribute does not occur
\end{tabular}

\section{Ice content}

The relative amount of ice contained in the soil. In the dominant and subdominant ice content files, the following values are used to represent the various groupings:

\begin{tabular}{ccl} 
Pixel & Original & \multicolumn{1}{c}{ Description } \\
Value & Code & \\
----- & ------- & ---------------------- \\
1 & L & Low \\
2 & M & Medium \\
3 & H & High \\
4 & $\#$ & Not applicable \\
5 & - & Attribute does not occur
\end{tabular}

\section{Permafrost occurrence}

The relative occurrence of permafrost in the soil of the area. In the dominant and subdominant permafrost occurrence files, the following values are used to represent the various groupings.

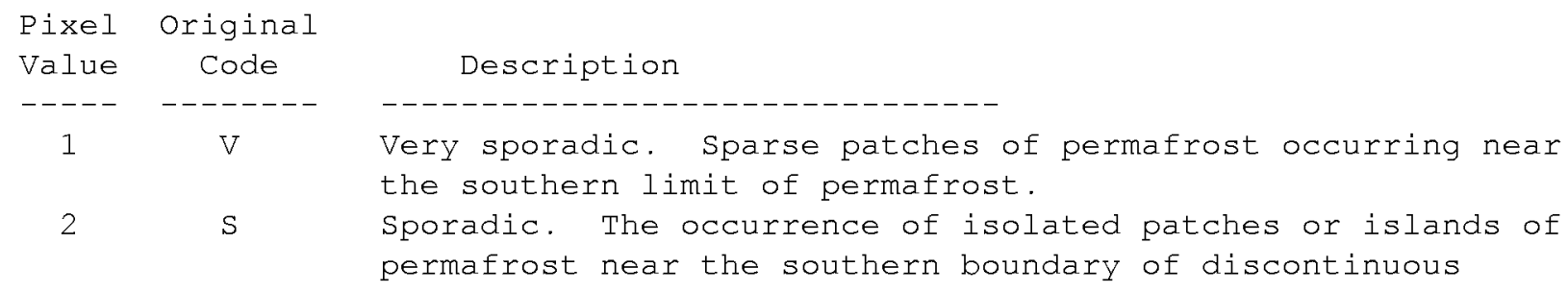



$3 \quad \mathrm{D}$
permafrost zone.
$4 \quad$ C
Discontinuous. Permafrost occurring in some areas beneath
the exposed land surface throughout a geographic region
where other areas are free of permafrost.
4 C Continuous. Permafrost occurring everywhere beneath the exposed land surface throughout a geographic region with the exception of widely scattered sites, such as newly deposited unconsolidated sediments.

$\begin{array}{ll}5 & \# \\ 6 & -\end{array}$
Not applicable.
Attribute does not occur.

\section{Active layer depth in soils with permafrost}

The depth of the top layer of ground subject to annual thawing and freezing in areas underlain by permafrost. The value in the file represents the depth of the active layer.

\section{Kind of patterned ground in soils with permafrost}

The types of geometrically shaped patterns found in soils with permafrost. In the dominant and subdominant kind of patterned ground files, the following values are used to represent the various groupings:

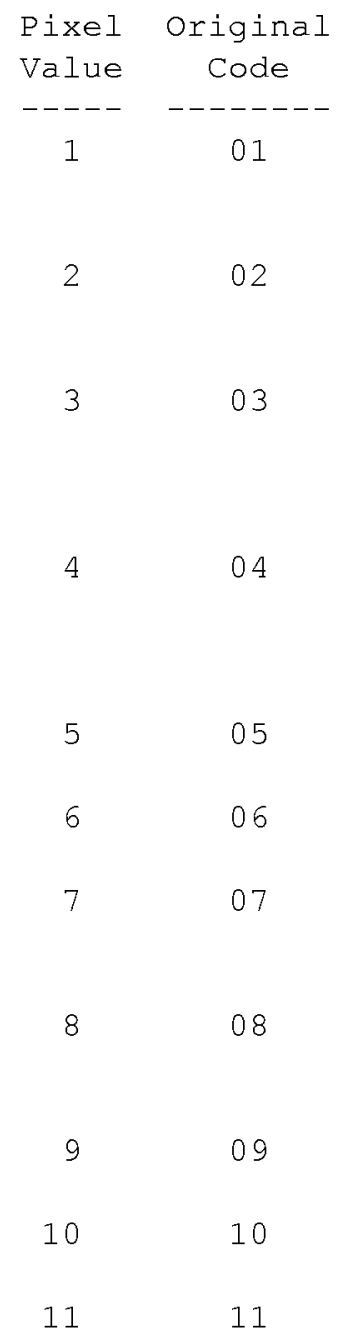




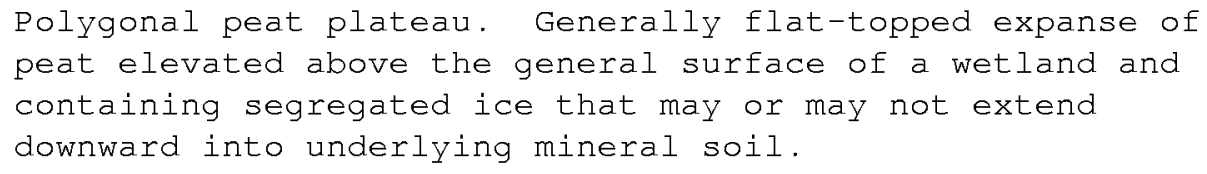

pH of upper $15 \mathrm{~cm}$ of soil measured in $\mathrm{CaCl}_{2}$

The $\mathrm{pH}$ of the upper $15 \mathrm{~cm}$ of soil as measured using $\mathrm{CaCl}_{2}$. The value in the file divided by 10 represents the $\mathrm{pH}$ of the upper $15 \mathrm{~cm}$ of soil.

pH of upper $15 \mathrm{~cm}$ of soil measured in water

The $\mathrm{pH}$ of the upper $15 \mathrm{~cm}$ of soil as measured using water. The value in the file divided by 10 represents the $\mathrm{pH}$ of the upper $15 \mathrm{~cm}$ of soil.

\section{Organic carbon of upper $15 \mathrm{~cm}$ of soil}

The percent of organic carbon contained in the upper $15 \mathrm{~cm}$ of soil. The value in the file represents the nearest percent of carbon in the top $15 \mathrm{~cm}$ of soil.

\section{Nitrogen content of upper $15 \mathrm{~cm}$ of soil}

The percent of nitrogen contained in the upper $15 \mathrm{~cm}$ of soil. In the dominant and subdominant nitrogen content files, the following values are used to represent the various groupings:

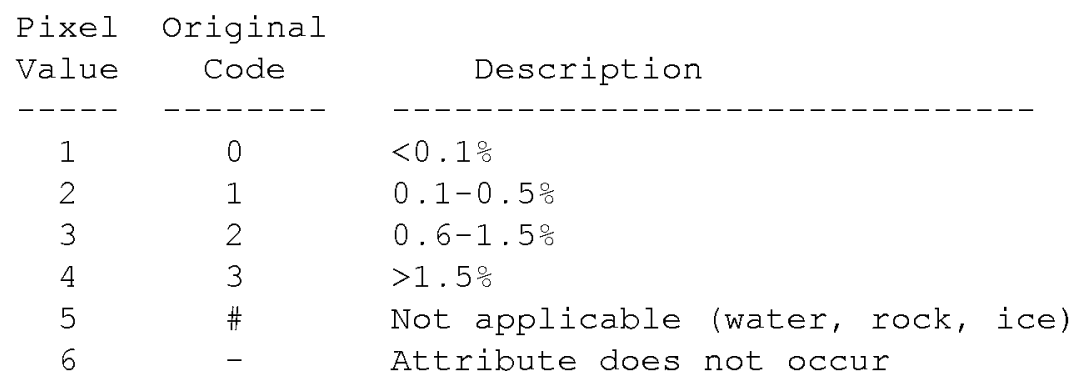

\section{Thickness of humus layer (L, F, H)}

The thickness categories for the humus layer. In the dominant and subdominant thickness of humus layer files, the following values are used to represent the various groupings:

\begin{tabular}{ccl} 
Pixel & Original \\
Value & Code & \multicolumn{1}{c}{ Description } \\
---- & ------- & ---------------------- \\
1 & 0 & $<5 \mathrm{~cm}$ \\
2 & 1 & $5-10 \mathrm{~cm}$ \\
3 & 2 & $11-20 \mathrm{~cm}$ \\
4 & 3 & $21-40 \mathrm{~cm}$ \\
5 & 4 & $>40 \mathrm{~cm}$ \\
6 & $\#$ & Not applicable (e.g., cultivated, eroded) \\
7 & - & Attribute does not occur
\end{tabular}




\section{Calcareous class of parent material}

The calcareous class of the parent material. In the dominant and subdominant calcareous class files, the following values are used to represent the various groupings:

\begin{tabular}{|c|c|c|}
\hline Value & Code & Description \\
\hline----- & -------- & 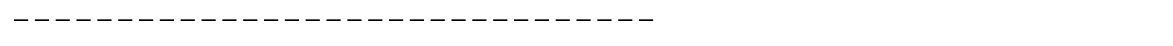 \\
\hline 1 & 0 & Noncalcareous. No $\mathrm{CaCO}_{3}$ detectable with dilute $\mathrm{HCl}$. \\
\hline 2 & 1 & $\begin{array}{l}\text { Weakly } 1-5 \% \mathrm{CaCO}_{3} \text { equivalents (weak effervescence with } \\
\text { dilute } \mathrm{HCl} \text { ). }\end{array}$ \\
\hline 3 & 2 & $\begin{array}{l}\text { Strongly. } \quad 6-40 \% \mathrm{CaCO}_{3} \text { equivalents (moderate to strong } \\
\text { effervescence with dilute } \mathrm{HCl} \text { ) }\end{array}$ \\
\hline 4 & 3 & $\begin{array}{l}\text { Extremely. }>40 \% \mathrm{CaCO}_{3} \text { equivalents (very strong } \\
\text { effervescence with dilute } \mathrm{HCl} \text { ) }\end{array}$ \\
\hline 5 & $\#$ & Not applicable (water, rock, ice). \\
\hline 6 & - & Attribute does not occur \\
\hline
\end{tabular}

\section{Inclusions 1}

The predominant type of inclusions found in the area. Inclusions may represent a maximum of $15 \%$ of the polygon area. Although their percent occupance is relatively small, they are generally strongly contrasting to the dominant or subdominant soil landscapes. A maximum of two inclusions may be recorded for each of the dominant and subdominant soil landscapes; a maximum of four inclusions may be recorded for each polygon. Inclusions provide an opportunity to document that "little bit" of extra information about the polygon. They may be associated with the dominant or subdominant soil landscape or they may occur independently. Extreme caution is recommended when using inclusions in area calculations. In the dominant and subdominant inclusions files, the following values are used to represent the various groupings:

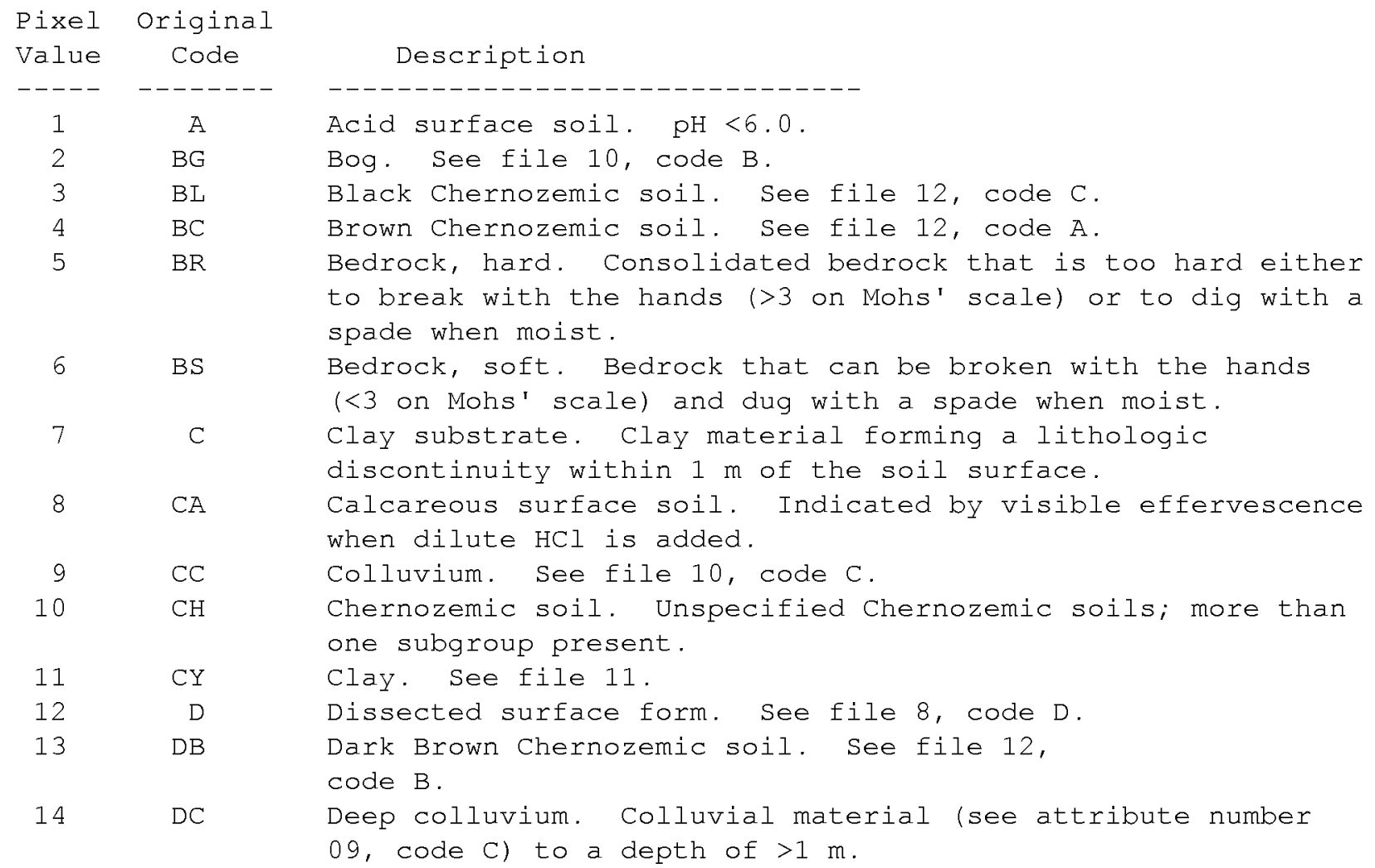




\begin{tabular}{|c|c|c|}
\hline 15 & DG & $\begin{array}{l}\text { Deep gravelly fluvioglacial. Gravelly fluvioglacial } \\
\text { material to a depth of }>1 \mathrm{~m} \text {; see file } 10 \text { (code } \\
\text { F) and } 11 \text {. }\end{array}$ \\
\hline 16 & DU & Duric material. See file 16, code D. \\
\hline 17 & $\mathrm{E}$ & $\begin{array}{l}\text { Eroded knolls. Relatively light-colored knolls compared to } \\
\text { other slope positions, occurring in hummocky or knoll-and- } \\
\text { kettle surface forms. }\end{array}$ \\
\hline 18 & $\mathrm{EO}$ & $\begin{array}{l}\text { Eolian material. }>50 \mathrm{~cm} \text { of eolian material (see file } 10 \text {, } \\
\text { code E). }\end{array}$ \\
\hline 19 & ES & Eroded slopes. Slopes eroded by water. \\
\hline 20 & $\mathrm{~F}$ & $\begin{array}{l}\text { Fluvioglacial substrate. Substrate of fluvioglacial } \\
\text { material (see file } 10 \text {, code F). }\end{array}$ \\
\hline 21 & $\mathrm{FH}$ & Ferro-Humic Podzolic soil. See attribute number 11 , code $V$. \\
\hline 22 & FO & Folisol. See file 12 , code 2 . \\
\hline 23 & $\mathrm{G}$ & $\begin{array}{l}\text { Sandy loam morainal material. Morainal material with a } \\
\text { sandy loam texture (see file } 11 \text { ). }\end{array}$ \\
\hline 24 & GG & Gravelly alluvium. See files 10 (code $A$ ) and 11 . \\
\hline 25 & GG & $\begin{array}{l}\text { Gravelly fluvioglacial material. See files } 10 \text { (code F) } \\
\text { and } 11 .\end{array}$ \\
\hline 26 & GL & $\begin{array}{l}\text { Gleyed soil. Presence of faint to distinct mottles lor } \\
\text { blotches) of different color interspersed within the } \\
\text { dominant matrix color. }\end{array}$ \\
\hline 27 & GM & Gravelly marine material. See files 10 (code $W$ ) and 11. \\
\hline 28 & GV & Orthic Gray Luvisolic soil. See file 12, code F. \\
\hline 29 & GY & Gleysolic soil. See file 12 , code $U$. \\
\hline 30 & $\mathrm{HC}$ & $\begin{array}{l}\text { Shallow lithic colluvium. Colluvial material (see file } 10 \text {, } \\
\text { code C) overlying a lithic contact } 50-100 \mathrm{~cm} \text { from } \\
\text { the surface. }\end{array}$ \\
\hline 31 & $\mathrm{HP}$ & Humo-Ferric Podzolic soil. See file 12, code $w$. \\
\hline 32 & HU & Hummocky surface form. See file 8, code H. \\
\hline 33 & I & $\begin{array}{l}\text { Brunisolic Gray Luvisolic soil. See file } 12, \\
\text { code I. }\end{array}$ \\
\hline 34 & IC & Ice. See file 5, code $C$. \\
\hline 35 & ID & Imperfectly drained soil. See file 18, code I. \\
\hline 36 & $\mathrm{~L}$ & Melanic Brunisolic soil. See file 12, code L. \\
\hline 37 & $\mathrm{LC}$ & Lacustrine material. see file 10, code L. \\
\hline 38 & $L F$ & Loamy alluvium material. See files 10 (code A) and 11. \\
\hline 39 & LI & $\begin{array}{l}\text { Lithic layer. Bedrock occurring within the normal depth of } \\
\text { soil development, usually within } 1 \mathrm{~m} \text { of the soil surface. }\end{array}$ \\
\hline 40 & LM & $\begin{array}{l}\text { Loamy morainal till. Till (or morainal) material in which } \\
\text { soil separates contain }<35 \% \text { clay and coarse fragments occupy } \\
<35 \% \text { by volume. }\end{array}$ \\
\hline 41 & LO & Loamy marine material. See files 10 (code $W$ ) and 11 . \\
\hline 42 & LS & Silty lacustrine material. See files 10 (code L) and 11 . \\
\hline 43 & LU & Luvisolic soil. See file 12, code E or F. \\
\hline 44 & M & Eutric Brunisolic soil. See file 12, code M. \\
\hline 45 & ML & $\begin{array}{l}\text { Clay loam marine material. See files } 10 \\
\text { (code } W \text { ) and } 11 .\end{array}$ \\
\hline 46 & MP & $\begin{array}{l}\text { Moss peat. Relatively undecomposed, spongy organic } \\
\text { material. }\end{array}$ \\
\hline 47 & $\mathrm{~N}$ & Sombric Brunisolic soil. See file 12, code $N$. \\
\hline 48 & NN & None. \\
\hline 49 & O & Organic material. See file 10, code 0 . \\
\hline 50 & OC & Organic Cryosolic soil. See file 12, code 0 . \\
\hline
\end{tabular}

Page 27 


\begin{tabular}{|c|c|c|}
\hline 51 & OT & Ortstein. See file 16, code 0. \\
\hline 52 & $\mathrm{P}$ & Dystric Brunisolic soil. See file 12, code P. \\
\hline 53 & $\mathrm{PD}$ & Poorly drained soil. See file 18, code P. \\
\hline 54 & $\mathrm{PP}$ & $\begin{array}{l}\text { Poorly drained, peat soil. Poorly drained soil with a peaty } \\
\text { surface layer }(<40 \mathrm{~cm} \text { thick). }\end{array}$ \\
\hline 55 & R1 & Soft rock outcrops. See file 5, code $R 1$. \\
\hline 56 & $\mathrm{R} 2$ & Hard rock outcrops, acidic. Granite rock outcrops. \\
\hline 57 & R3 & Hard rock outcrops, basic. Limestone rock outcrops. \\
\hline 58 & R4 & $\begin{array}{l}\text { Hard rock outcrops, undifferentiated. See attribute number } \\
03 \text {, code } 44 \text {. }\end{array}$ \\
\hline 59 & $\mathrm{RD}$ & Rapidly drained soil. See file 18, code R. \\
\hline 60 & RG & Regosolic soil. See file 12, code R. \\
\hline 61 & $\mathrm{SA}$ & $\begin{array}{l}\text { Saline soil. Soil causing an obvious reduction in crop } \\
\text { growth, may have white surface crust. }\end{array}$ \\
\hline 62 & $\mathrm{SC}$ & Static Cryosolic soil. See file 12, code $\mathrm{S}$ \\
\hline 63 & $\mathrm{SD}$ & $\begin{array}{l}\text { Sandy marine material. Marine material with a sand texture } \\
\text { class; see files } 10 \text { (code } A \text { ) and } 11 \text {. }\end{array}$ \\
\hline 64 & $\mathrm{SF}$ & Sandy alluvium. See attribute numbers 09 (code $A$ ) and 10 \\
\hline 65 & SG & $\begin{array}{l}\text { Sandy fluvioglacial material. Fluvioglacial material but } \\
\text { with a sand texture class; see files } 10 \text { (code F) and } 11 .\end{array}$ \\
\hline 66 & $\mathrm{SH}$ & Gravelly shoreline. See file 11 \\
\hline 67 & SL & Silty alluvium. See files 10 (code A) and 11 . \\
\hline 68 & SO & $\begin{array}{l}\text { Sombric Humo-Ferric Podzolic soil. See file } 12, \\
\text { code } W .\end{array}$ \\
\hline 69 & $\mathrm{SP}$ & Steep surface form. See file 8 , code $S$. \\
\hline 70 & SS & Silty surface texture. See file 11. \\
\hline 71 & $\mathrm{ST}$ & $\begin{array}{l}\text { Stony surface. Sufficient stones to seriously handicap } \\
\text { cultivation. }\end{array}$ \\
\hline 72 & SY & Sandy material. See file 11 \\
\hline 73 & $\mathrm{~T}$ & $\begin{array}{l}\text { Till substrate. Till (or morainal) material forming a } \\
\text { lithologic discontinuity within } 1 \mathrm{~m} \text { of the soil surface. }\end{array}$ \\
\hline 74 & TA & $\begin{array}{l}\text { Talus. Sloping mass of rock fragments below a cliff or at } \\
\text { the foot of a steep slope. }\end{array}$ \\
\hline 75 & $\mathrm{TC}$ & Turbic Cryosolic soil. See file 12, code $T$. \\
\hline 76 & $\mathrm{TE}$ & $\begin{array}{l}\text { Terric layer. Unconsolidated mineral substratum occurring } \\
\text { within the normal depth of organic soil development } \\
(40-160 \mathrm{~cm}) .\end{array}$ \\
\hline 77 & TR & Terraced surface form. See file 8, code $T$. \\
\hline 78 & $\mathrm{TT}$ & Anthropogenic material. See file 10, code T. \\
\hline 79 & VA & $\begin{array}{l}\text { Volcanic ash. Deposition of fine, wind-transported material } \\
\text { of volcanic origin deposited in thin layers that persist for } \\
\text { along time in bogs, river terraces, talus slopes, and kettle } \\
\text { holes. }\end{array}$ \\
\hline 80 & VS & $\begin{array}{l}\text { Very shallow lithic layer. Rock material occurring at }<50 \\
\text { cm from the surface. }\end{array}$ \\
\hline 81 & WD & Well-drained soil. See file 18, code $W$ \\
\hline 82 & WE & $\begin{array}{l}\text { Wind erosion. Removal of surface soil particles caused by } \\
\text { wind action. }\end{array}$ \\
\hline 83 & WT & $\begin{array}{l}\text { Wetlands. Lands dominated by the persistent presence of } \\
\text { excess water indicated by Gleysolic and shallow Organic } \\
\text { soils under a cover of hydrophytic vegetation. }\end{array}$ \\
\hline 84 & $\mathrm{X}$ & Fibrisol. See file 12, code $X$. \\
\hline 85 & Y & Mesisol. See file 12, code Y. \\
\hline 86 & Z & Humisol. See file 12 , code $Z$. \\
\hline
\end{tabular}

Page 28 
Fibric-sphagnum soil. Sphagnum organic soil in the stage of decomposition in which fibric materials are readily identifiable as to botanical origin.

\begin{tabular}{|c|c|c|}
\hline 88 & 14 & Patterned ground. See file 25. \\
\hline 89 & 17 & $\begin{array}{l}\text { Bouldery material. Rounded or irregular coarse fragments } \\
>60 \mathrm{~cm} \text { in diameter. }\end{array}$ \\
\hline 90 & 21 & $\begin{array}{l}\text { Mesic-sedge material. Sedge organic material in a mesic (or } \\
\text { intermediate) degree of decomposition. }\end{array}$ \\
\hline 91 & 23 & $\begin{array}{l}\text { Mesic woody-forest material. Woody-forest organic material } \\
\text { in a mesic degree of decomposition; the material is partly } \\
\text { altered physically and biochemically. }\end{array}$ \\
\hline & \# & Not applicable. \\
\hline & - & Attribute does not occur. \\
\hline & 22 & (Not in original documentation.) \\
\hline
\end{tabular}

\section{Inclusions 2}

The secondary type of inclusions found. In the dominant and subdominant inclusions files, the same values are used as for inclusions 1 described previously.

\section{Vegetative cover or land use, or both}

The category of vegetative cover or type of land use in the area. In the dominant and subdominant vegetative cover or land use files, the following values are used to represent the various groupings:

\begin{tabular}{|c|c|c|}
\hline Value & Code & Description \\
\hline----- & -------- & -------------------------------- \\
\hline 1 & A & Agricultural crops. Annual field crops. \\
\hline 2 & B & $\begin{array}{l}\text { Bog. Bogs may be treed or treeless and are usually covered } \\
\text { with sphagnum spp. and ericaceous shrubs. }\end{array}$ \\
\hline 3 & $\mathrm{C}$ & $\begin{array}{l}\text { Coniferous forest. Dominated by needle-leaved, cone-bearing } \\
\text { species. }\end{array}$ \\
\hline 4 & $\mathrm{D}$ & Deciduous forest. Dominated by broadleaf species. \\
\hline 5 & $\mathrm{E}$ & $\begin{array}{l}\text { Fen. Dominated by sedges, grasses, reeds, and brown mosses } \\
\text { with some shrubs and, at times, a sparse tree layer. }\end{array}$ \\
\hline 6 & G & Grassland. Perennial native grassland or improved pasture. \\
\hline 7 & $\mathrm{H}$ & $\begin{array}{l}\text { Arctic desert. Unvegetated areas in the polar desert of the } \\
\text { high Arctic; may be caused by either climatic (too cold or } \\
\text { too dry) or edaphic (low soil nutrients or toxic substrate) } \\
\text { factors, or a combination of both. }\end{array}$ \\
\hline 8 & M & Mixed deciduous and coniferous forest. See codes C and D. \\
\hline 9 & $\mathrm{P}$ & $\begin{array}{l}\text { Parkland. A forest-grassland transition comprising a mosaic } \\
\text { of trembling aspen stands interspersed with patches of } \\
\text { cropland, grassland, and meadow. }\end{array}$ \\
\hline 10 & $\mathrm{R}$ & $\begin{array}{l}\text { Marshland. A mosaic surface pattern composed of pools or } \\
\text { channels interspersed with clumps of emergent sedges, } \\
\text { grasses, rushes, and reeds, bordering grassy meadows, and } \\
\text { peripheral bands of shrubs or trees; submerged and floating } \\
\text { aquatics flourish in open water areas. }\end{array}$ \\
\hline 11 & S & Shrubland. Dominated by shrub species. \\
\hline 12 & SP & $\begin{array}{l}\text { Sedge peat. Dominated by Carex spp. and generally } \\
\text { moderately decomposed and matted; the sedge leaves are } \\
\text { readily identifiable to the naked eye. }\end{array}$ \\
\hline 13 & TA & $\begin{array}{l}\text { Tundra, alpine. Treeless terrain found at high altitudes } \\
\text { occurring immediately above the forest zone and the upper }\end{array}$ \\
\hline
\end{tabular}




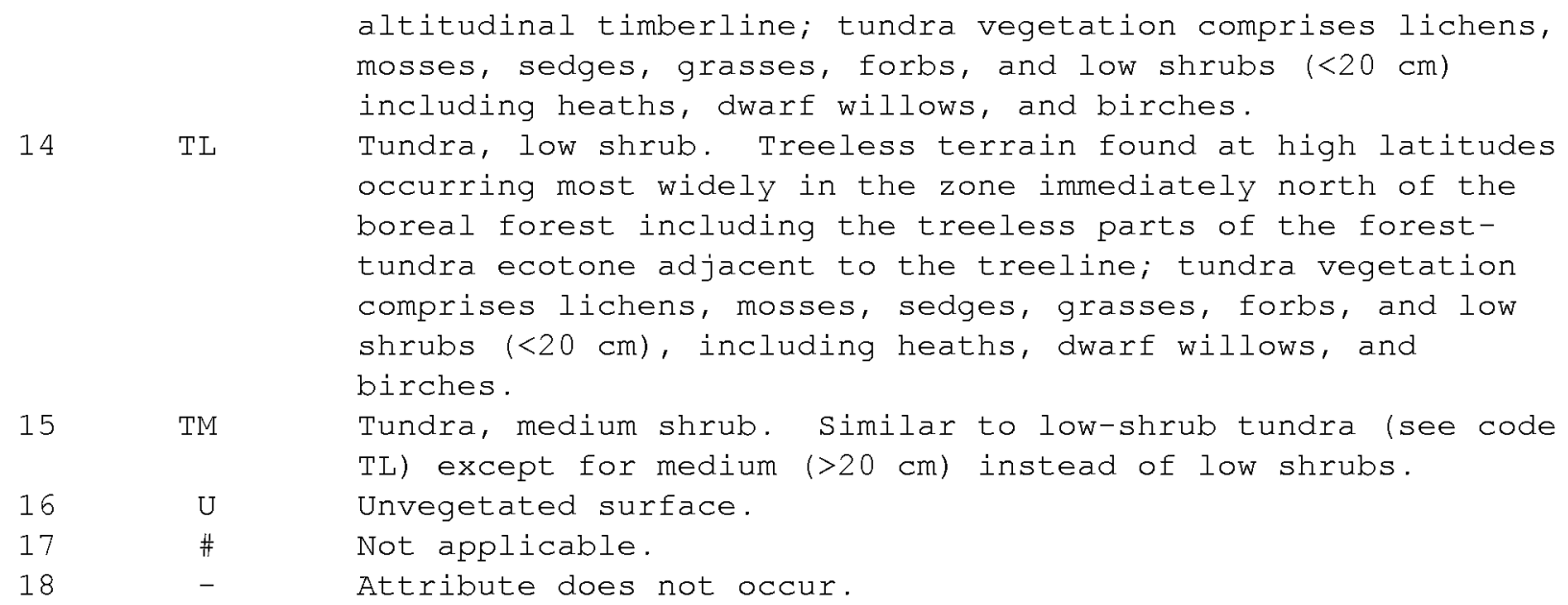

Lake size estimated from Landsat imagery

The size category of a lake that exists over the area. In the dominant and subdominant lake size files, the following values are used to represent the various groupings:

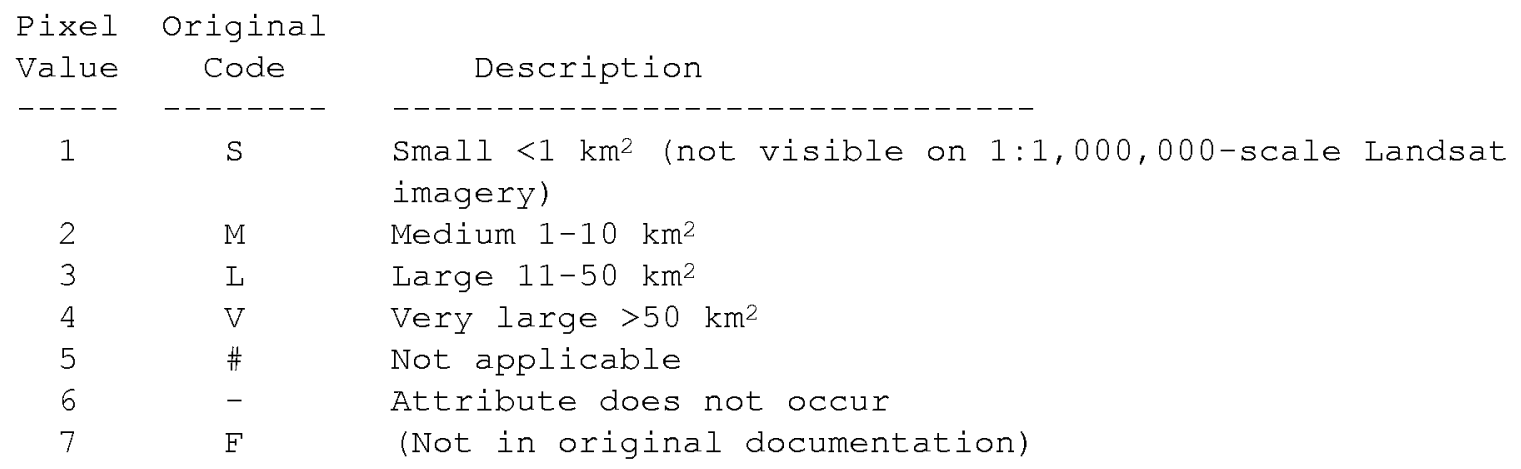

The percent levels of the area covered by water bodies that are wholly contained within the polygon as estimated from Landsat images. In the dominant and subdominant percent water body files, the following values are used to represent the various groupings:

$\begin{array}{cc}\text { Pixel } & \text { Original } \\ \text { Value } & \text { Code } \\ ----- & ------- \\ 1 & \text { F } \\ 2 & \text { C } \\ 3 & \text { M } \\ 4 & \text { A } \\ 5 & \# \\ 6 & -\end{array}$

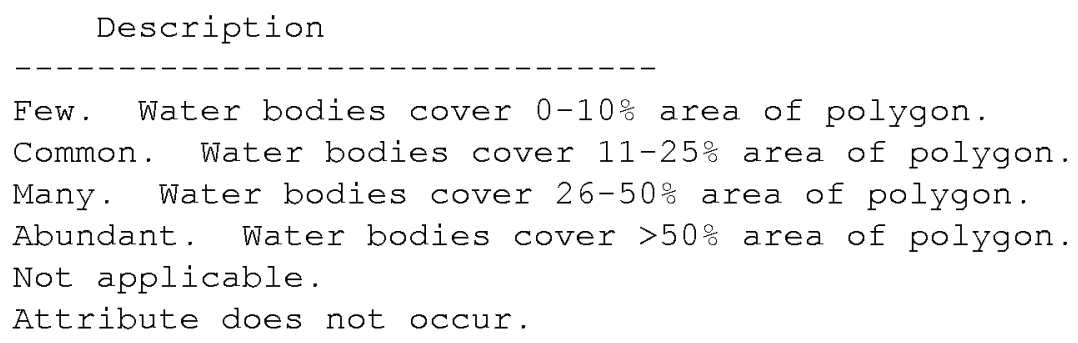




\section{Reliability class of polygon}

The relative reliability of the information provided for the polygon. In the dominant and subdominant reliability class files, the following values are used to represent the various groupings:

\begin{tabular}{|c|c|c|}
\hline Value & Code & Description \\
\hline----- & -------- & ------------------------------- \\
\hline 1 & $\mathrm{~V}$ & $\begin{array}{l}\text { Very low. Compiled from interpretation of Landsat data } \\
\text { only; no ground data are collected for verification of these } \\
\text { areas. }\end{array}$ \\
\hline 2 & $\mathrm{~L}$ & $\begin{array}{l}\text { Low. Compiled from soil survey maps produced from field } \\
\text { traverses at wide intervals (up to } 10 \mathrm{~km} \text { ) and without the } \\
\text { use of aerial photographs, or compiled from maps produced by } \\
\text { inspections using fixed-wing aircraft or helicopter and } \\
\text { aided by interpretation of Landsat imagery. }\end{array}$ \\
\hline 3 & M & $\begin{array}{l}\text { Medium. Produced from systematic traverses by helicopter } \\
\text { and by interpretation of stereoscopic aerial photographs, } \\
\text { or compiled from modern soil survey procedures, which } \\
\text { include traversing existing accessible roads in wilderness } \\
\text { areas, and aided by interpretation of stereoscopic aerial } \\
\text { photographs. }\end{array}$ \\
\hline 4 & $\mathrm{H}$ & $\begin{array}{l}\text { High. Compiled from modern soil survey maps produced from } \\
\text { field traverses at < } 1.6-\mathrm{km} \text { intervals and with the aid of } \\
\text { stereoscopic aerial photographs. }\end{array}$ \\
\hline 5 & \# & Not applicable. \\
\hline 6 & - & Attribute does not occur. \\
\hline
\end{tabular}

\section{Complexity class of polygon (8-bit integers)}

The relative complexity or variability of the soil in the area. In the dominant and subdominant complexity class files, the following values are used to represent the various groupings:

\begin{tabular}{|c|c|c|}
\hline Value & Code & Description \\
\hline----- & -------- & ------------------------------- \\
\hline 1 & $\mathrm{~L}$ & $\begin{array}{l}\text { Low. Soil and landscape attributes within the polygon are } \\
\text { uniform for most interpretations; in most cases the polygon } \\
\text { has only a dominant component. }\end{array}$ \\
\hline 2 & $\mathrm{M}$ & $\begin{array}{l}\text { Medium. Soil and landscape attributes are moderately } \\
\text { variable but predictable; there are generally dominant and } \\
\text { subdominant components, each of which usually has been } \\
\text { generalized from no more than two classes of parent material } \\
\text { or soil development, or both; there may also be an inclusion } \\
\text { in the polygon. }\end{array}$ \\
\hline 3 & $\mathrm{H}$ & $\begin{array}{l}\text { High. Soil and landscape attributes are highly variable and } \\
\text { unpredictable; dominant, subdominant, and inclusion } \\
\text { components are present, each of which has been generalized } \\
\text { from more than two classes of parent material or soil } \\
\text { development, or both; use this class to warn of extreme } \\
\text { oversimplification in any interpretations from the extended } \\
\text { legend. }\end{array}$ \\
\hline 4 & \# & Not applicable. \\
\hline & - & Attribute does not occur. \\
\hline
\end{tabular}

Page 31 


\section{Soil name numbers (files 1 and 2)}

The binary number in the dominant and subdominant soil name number raster files for Saskatchewan and Manitoba that are used to look up pertinent information in the American Standard Code for Information Interchange (ASCII) soil name files.

\section{Parent material textural group}

The texture group of the parent material. In the dominant and subdominant parent material texture files, the following values are used to represent the various groupings:

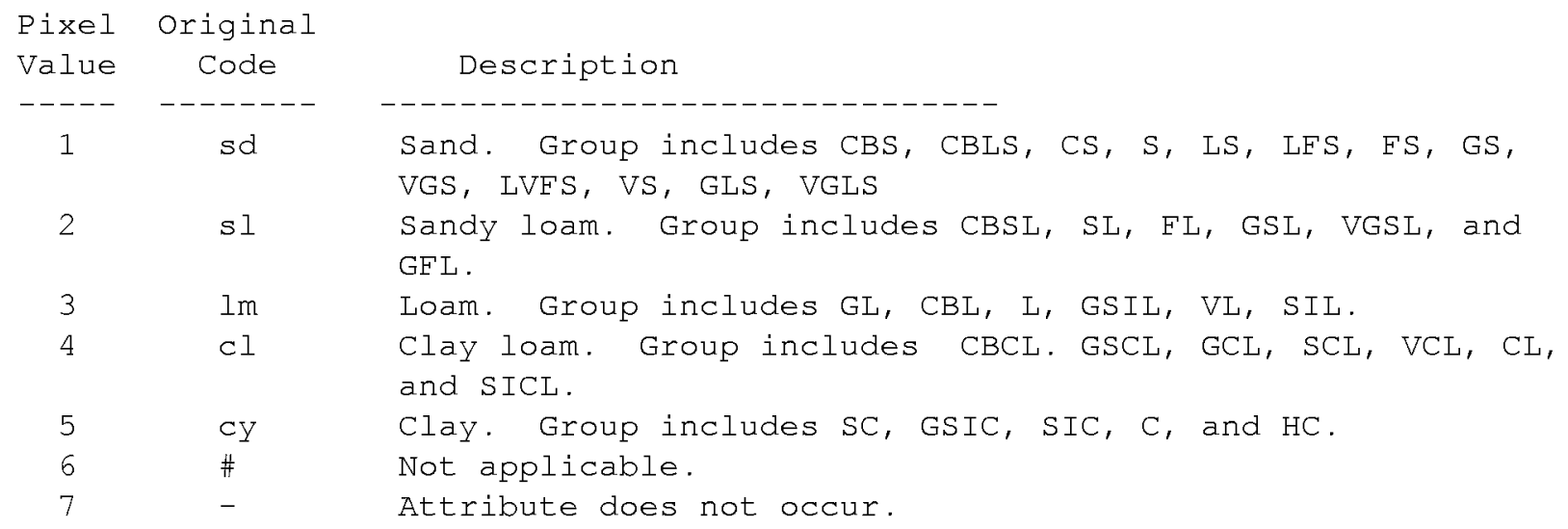

The following describes the soil names files and how to decode the various columns of data that they contain.Soil Names Supplemental Information for Saskatchewan (ASCII): The columns of this file are listed in the following order:

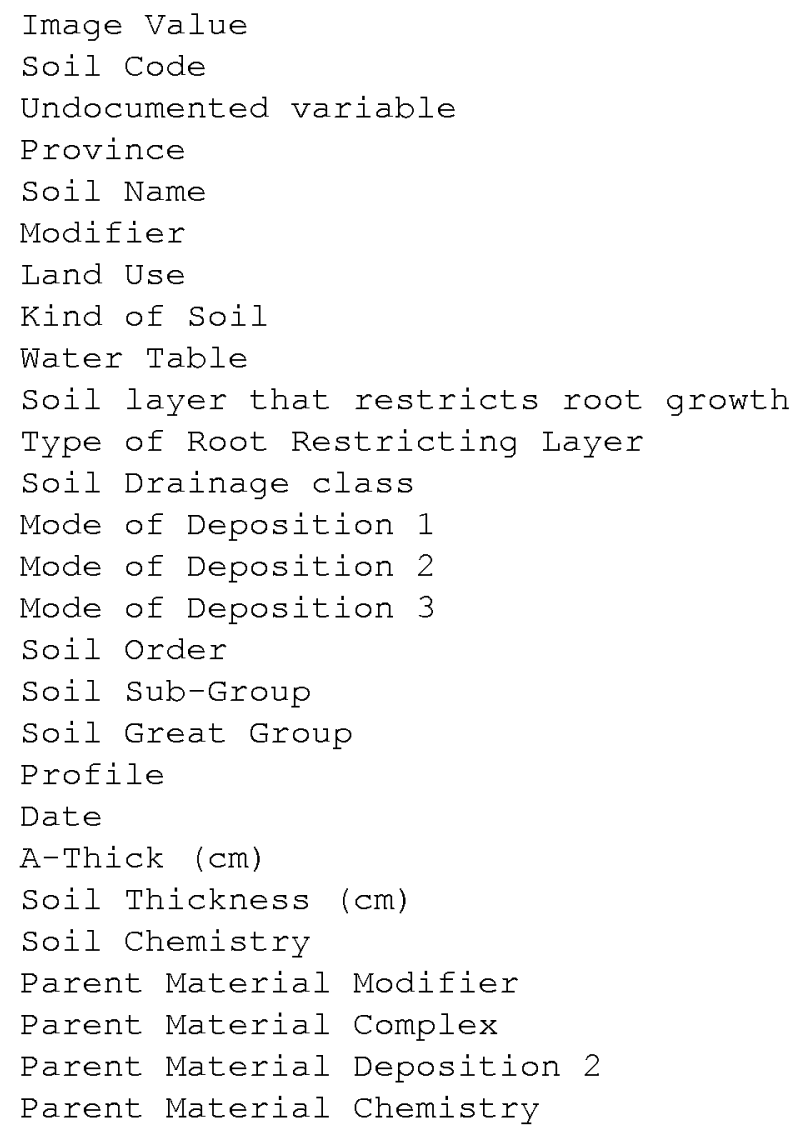


Parent Material Textural Class

Texture Modifier

Eamily Particle Size

Physiographic

Soil Names Supplemental Information for Manitoba (ASCII): The columns of this file are listed in the following order:

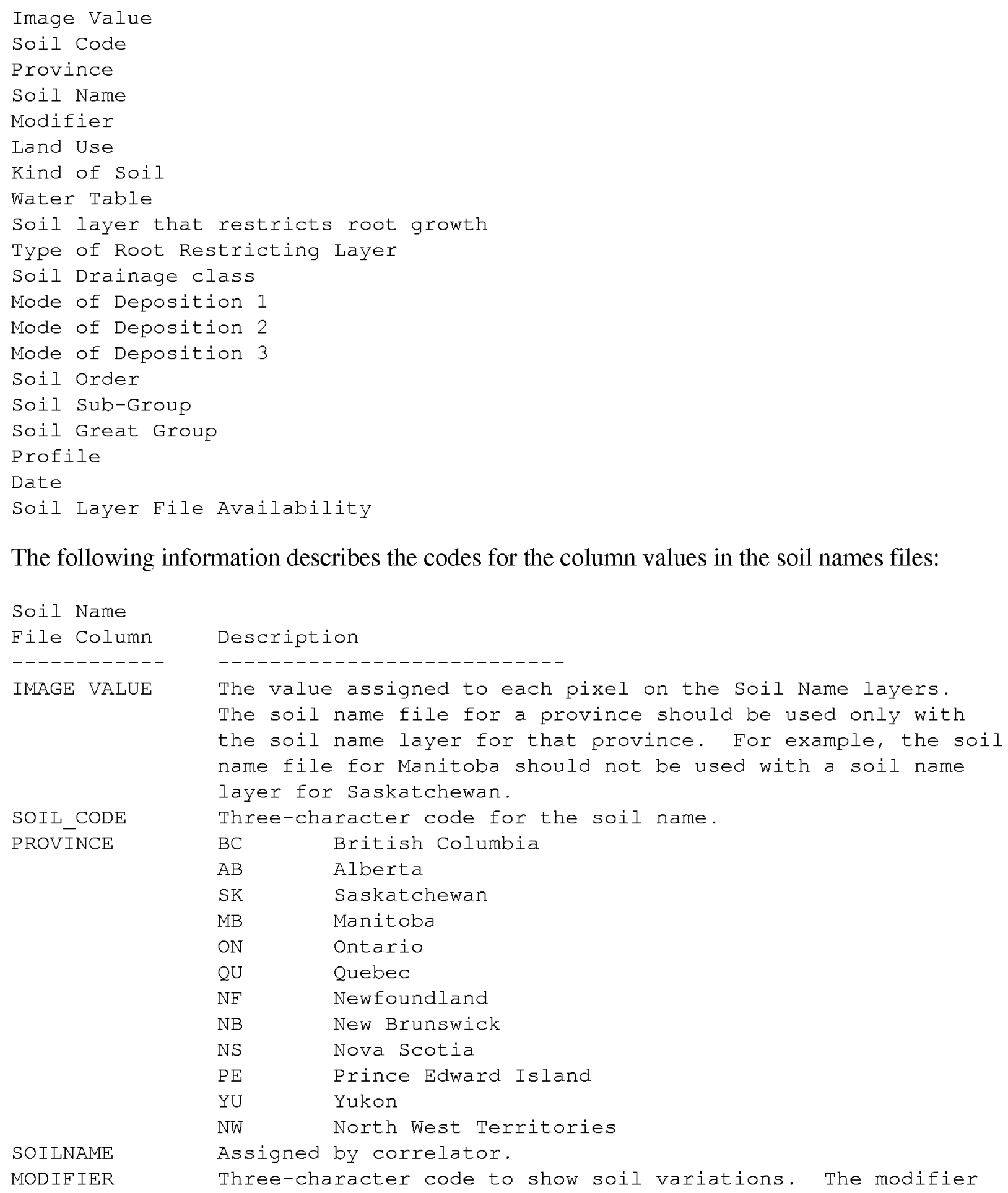

The following information describes the codes for the column values in the soil names files: 
LU

KIND

WATERTBL

ROOTRESTR

RESTR_TYPE

DRAINAGE

MDEP applies to the soil name and the soil code. Land use:

N Native conditions

A Agriculture

Kind of soil.

M Mineral

O Organic

$\mathrm{N} \quad$ Nonsoil

U Unclassified or incomplete

Water table characteristics:

- Not applicable

No Not present at any time

YU Present during unspecified time

YG Present during growing season

YN Present during nongrowing season

YB Present during both seasons

soil layer that restricts root growth:

- Not applicable

o Not present

1-9 Restricting layer number (in SLF)

Type of root restricting layer:

- Not applicable

UN Undifferentiated

$\mathrm{BN}$ Solonetzic B

$\mathrm{SA} \quad \mathrm{EC}>4 \mathrm{dS} / \mathrm{m}$

CT Compact (Basal) Till

OR Ortstein

FP Fragipan

LI Lithic

CR Cryic

DU Duric

PL Placic

Soil drainage class:

- Not applicable

VR Very Rapidly

R Rapidly

W Well

MW Moderately Well

I Imperfectly

P Poorly

VP Very Poorly

Mode of deposition (and MDEP1, MDEP2, MDEP3)

$-$

Not Applicable

ANTH Anthropogenic

COLL Colluvial

EOLI Eolian

FLEO Fluvioeolian

FLLC Fluviolacustrine

FLUV Fluvial

FNPT Fen Peat

FOPT Forest Peat

GLFL Glaciofluvial

GLLC Glaciolacustrine

GLMA Glaciomarine

Page 34 


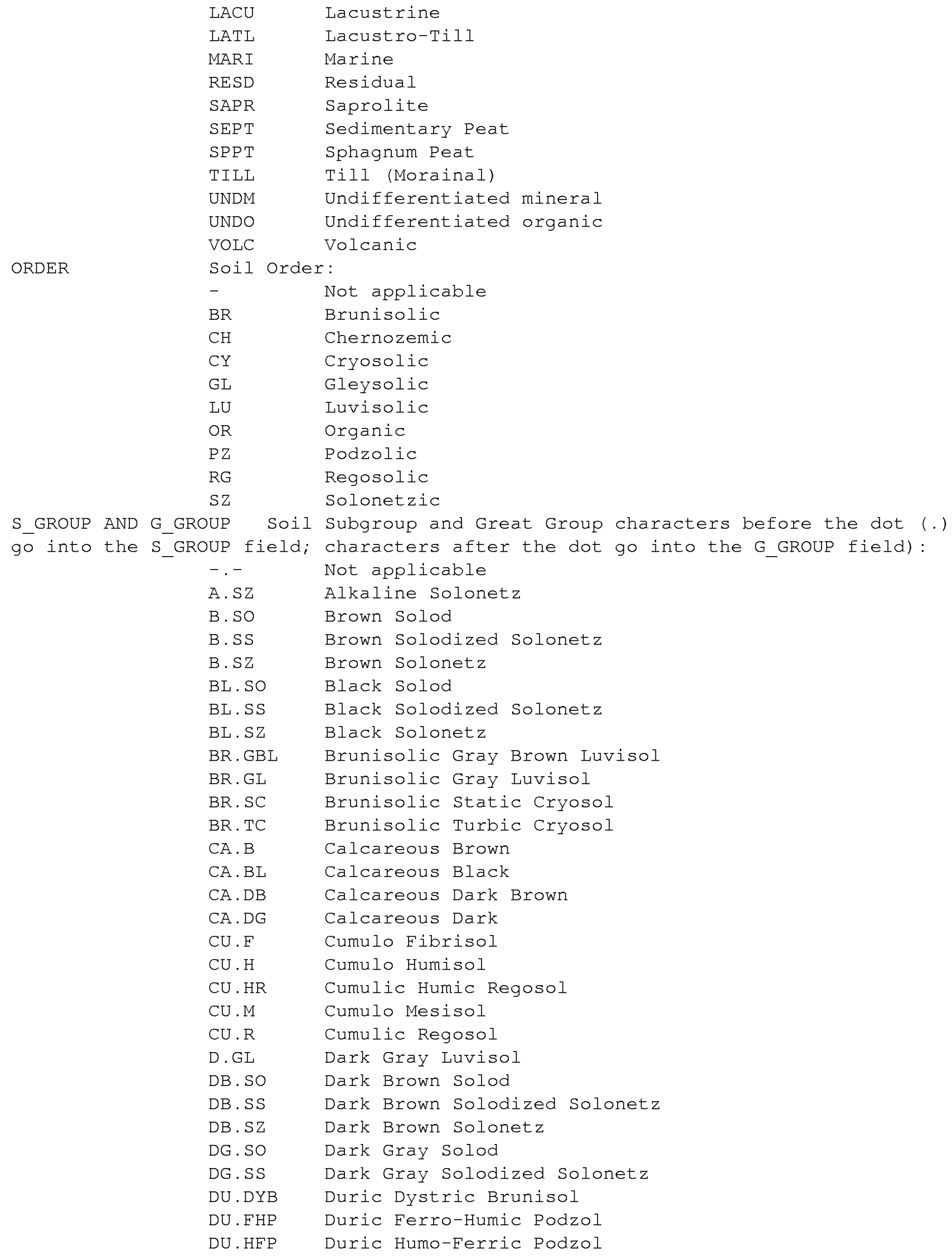




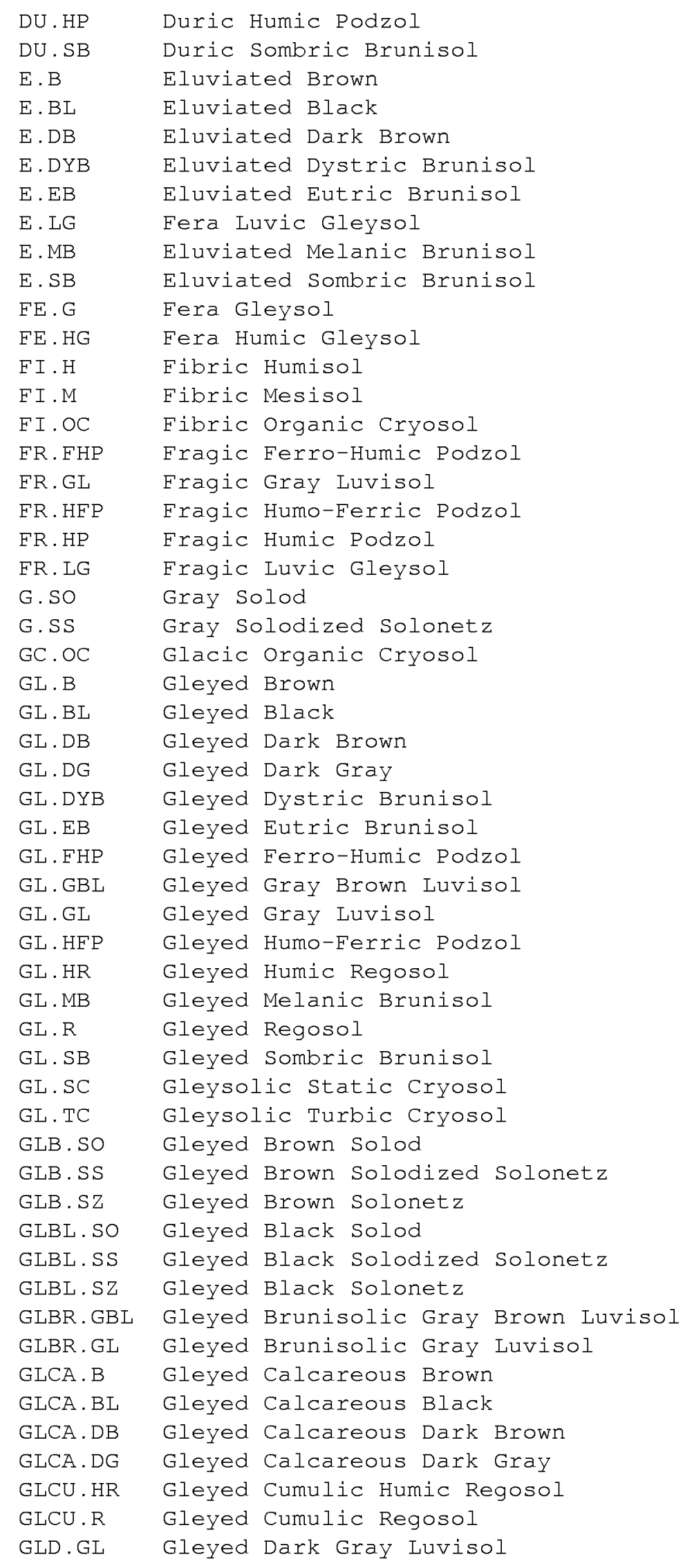




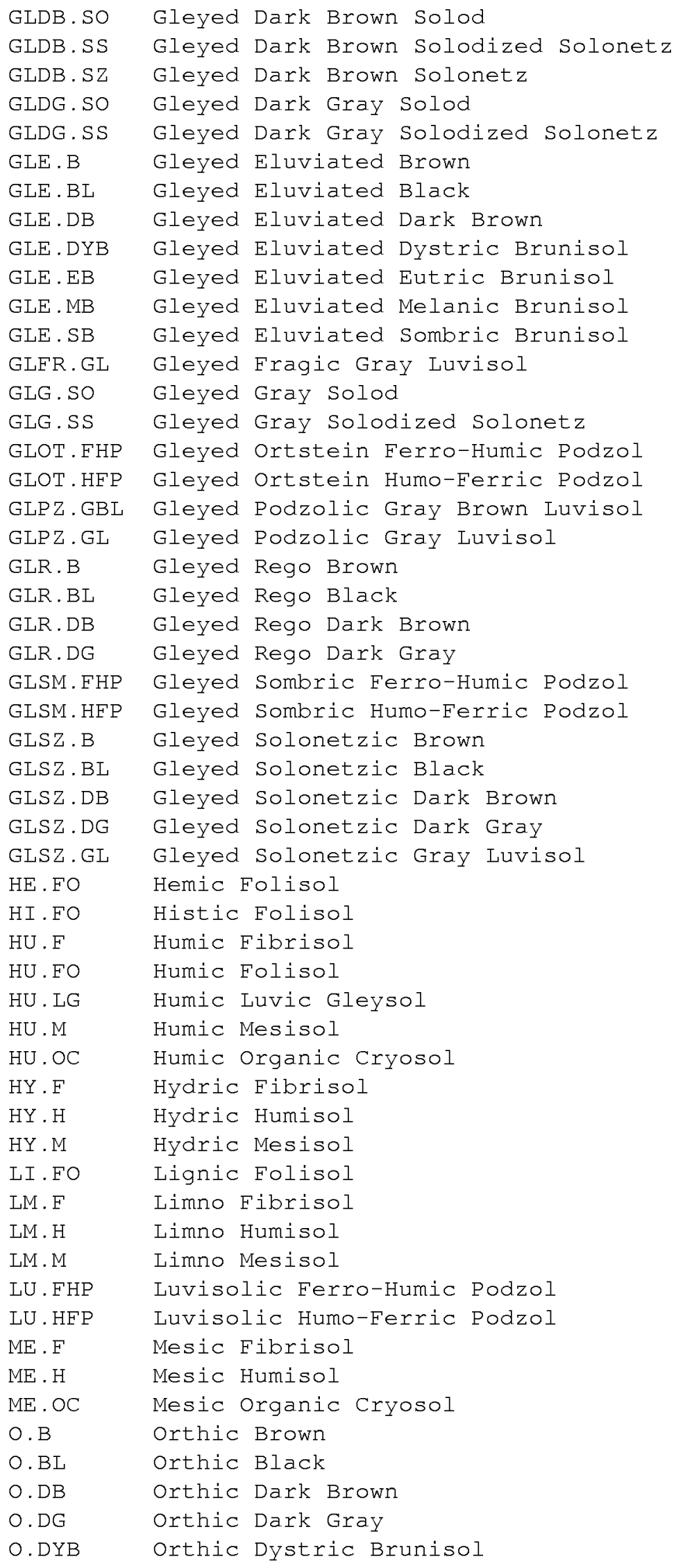

Page 37 


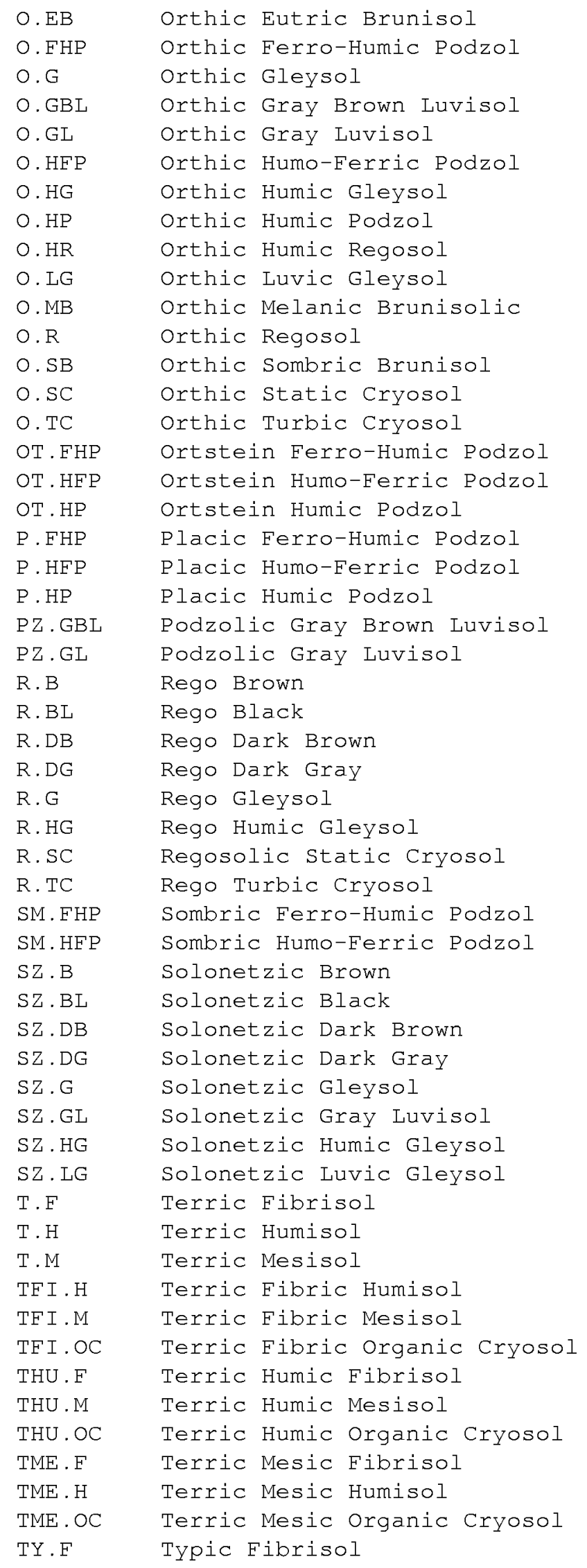




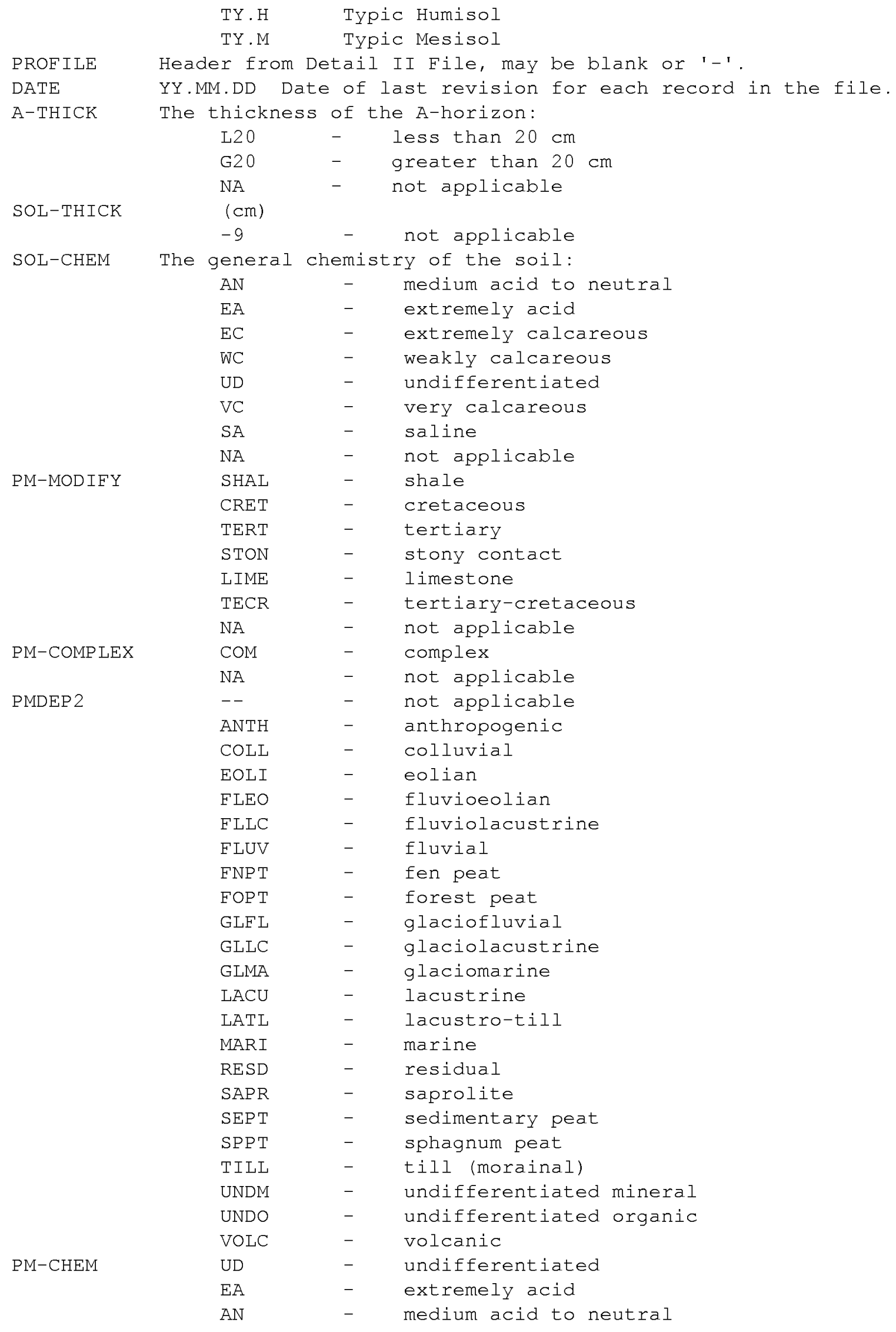

Page 39 


\begin{tabular}{|c|c|c|c|}
\hline & WC & - & weakly calcareous \\
\hline & $\mathrm{VC}$ & - & very calcareous \\
\hline & $\mathrm{EC}$ & - & extremely calcareous \\
\hline & $S A$ & - & saline \\
\hline & NA & - & not applicable \\
\hline PMTEXCLASS & VCS & - & very coarse sand \\
\hline & CS & - & coarse sand \\
\hline & LCS & - & loamy coarse sand \\
\hline & S & - & sand \\
\hline & FS & - & fine sand \\
\hline & LS & - & loamy sand \\
\hline & LFS & - & loamy fine sand \\
\hline & VES & - & very fine sand \\
\hline & LVFS & - & loamy very fine sand \\
\hline & CSL & - & coarse sandy loam \\
\hline & SL & - & sandy loam \\
\hline & FSL & - & fine sandy loam \\
\hline & VFSL & - & very fine sandy loam \\
\hline & $\mathrm{L}$ & - & loam \\
\hline & SIL & - & silt loam \\
\hline & SCL & - & sandy clay loam \\
\hline & SICL & - & silty clay loam \\
\hline & $\mathrm{CL}$ & - & clay loam \\
\hline & $\mathrm{C}$ & - & clay \\
\hline & $\mathrm{HC}$ & - & heavy clay \\
\hline & 0 & - & organic \\
\hline & $\mathrm{F}$ & - & fibric \\
\hline & M & - & mesic \\
\hline & $\mathrm{H}$ & - & humic \\
\hline & NA & - & not applicable \\
\hline TEXMODIFY & GR & - & gravelly \\
\hline & VG & - & very gravelly \\
\hline & WY & - & woody \\
\hline & NA & - & not applicable \\
\hline FAMPARTS 12 & UD & - & undifferentiated \\
\hline & $\mathrm{FR}$ & - & fragmental \\
\hline & SK & - & skeletal \\
\hline & SY & - & sandy \\
\hline & CL & - & coarse loamy \\
\hline & FL & - & fine loamy \\
\hline & $L Y$ & - & loamy \\
\hline & $\mathrm{CY}$ & - & clayey \\
\hline & SM & - & stratified mineral \\
\hline & SU & - & stratified mineral and organic \\
\hline & so & - & stratified organic \\
\hline & OG & - & organic \\
\hline & WY & - & woody \\
\hline & FI & - & fibric \\
\hline & $\mathrm{ME}$ & - & mesic \\
\hline & $\mathrm{HU}$ & - & humic \\
\hline & RU & - & bedrock undifferentiated \\
\hline & RA & - & bedrock acid \\
\hline & $\mathrm{RB}$ & - & bedrock basic \\
\hline & RS & - & bedrock soft \\
\hline
\end{tabular}

Page 40 


$\begin{array}{llll} & \text { NA } & - & \text { not applicable } \\ \text { PHYSIOG } & \text { PHY } & - & \text { physiographic } \\ \text { NA } & - & \text { not applicable }\end{array}$

\subsubsection{Unit of Measurement}

- $\quad$ Provincial Code - Unitless but coded value.

- Polygon Number - Unitless but coded value.

- Surface material - Unitless but coded value.

- $\quad$ Percentage distribution of dominant and subdominant soil landscapes - Percent.

- Regional landform - Unitless but coded value.

- Local surface form - Unitless but coded value.

- $\quad$ Slope gradient class - Unitless but coded value.

- $\quad$ Soil parent material mode of deposition (or origin) - Unitless but coded value.

- $\quad$ Parent material texture - Unitless but coded value.

- Soil development - Unitless but coded value.

- Surface texture of mineral soil to $15 \mathrm{~cm}$ - Unitless but coded value.

- Coarse fragment content of mineral soils - Unitless but coded value.

- $\quad$ Rooting depth, unrestricted - Unitless but coded value.

- $\quad$ Kind of compacted, consolidated, or contrasting layer - None.

- Depth to compacted, consolidated, or contrasting layer - None.

- Drainage class - Unitless but coded value.

- Available water capacity in upper $120 \mathrm{~cm}$ - Unitless but coded value.

- $\quad$ Average depth to water table - Unitless but coded value.

- $\quad$ Ice type - Unitless but coded value.

- Ice content - Unitless but coded value.

- Permafrost occurrence - Unitless but coded value.

- $\quad$ Active layer depth in soils with permafrost - centimeters.

- $\quad$ Kind of patterned ground in soils with permafrost - Unitless but coded value.

- $\quad \mathrm{pH}$ of upper $15 \mathrm{~cm}$ of soil measured in $\mathrm{CaCl}_{2}$ - Tenths of $\mathrm{pH}$ units. Divide by 10 .

- $\quad \mathrm{pH}$ of upper $15 \mathrm{~cm}$ of soil measured in water - Tenths of $\mathrm{pH}$ units. Divide by 10.

- Organic carbon of upper $15 \mathrm{~cm}$ of soil - Percent.

- Nitrogen content of upper $15 \mathrm{~cm}$ of soil - Unitless but coded value.

- Thickness of humus layer (L, F, H) - Unitless but coded value.

- Calcareous class of parent material - Unitless but coded value.

- Inclusions 1 - Unitless but coded value.

- Inclusions 2 - Unitless but coded value.

- Vegetative cover or land use, or both - Unitless but coded value.

- $\quad$ Lake size estimated from Landsat imagery - Unitless but coded value.

- $\quad$ Reliability class of polygon - Unitless but coded value.

- Complexity class of polygon - Unitless but coded value.

- $\quad$ Soil name 1 - Unitless but coded value.

- $\quad$ Soil name 2 - Unitless but coded value.

- $\quad$ Parent material textural group - Unitless but coded value.

- Soil Names Supplemental Information for Saskatchewan - See the end of Section 7.3.2 for descriptions of the columns in the file.

- Soil Names Supplemental Information for Manitoba - See the end of Section 7.3.2 for descriptions of the columns in the file.

\subsubsection{Data Source}

The original vector data set was produced by Agriculture Canada and was acquired from:

CanSIS Project Leader

Land Resource Research Centre

Research Branch, Agriculture Canada 
Central Experiment Farm

K.W. Neatby Building

Ottawa, Ontario K1A 0C6

\subsubsection{Data Range}

The various data layers have different data ranges. Some of the potential values are listed under the variable descriptions provided in Section 7.3.2.

\subsection{Sample Data Record}

Not applicable for raster data files.

\section{Data Organization}

\subsection{Data Granularity}

The smallest amount of obtainable data is the entire data set containing all of the raster layers and their supporting files.

\subsection{Data Format(s)}

\subsubsection{Uncompressed Data Files}

The regional soils product contains 83 total files, of which some contain ASCII information and others contain binary numbers. The first file is a descriptive ASCII header file that describes the content of the other files. The next three binary files (files 2 to 4 ) contain information about the data for the respective provinces. Files 5 to 43 (39 files) contain binary values for the dominant soil landscape features. The last 39 files (files 44 to 81 ) contain binary values for the subdominant soil landscape features. Files 82 and 83 contain the soil name files for Saskatchewan and Manitoba, respectively.

Separate binary files exist for each of the various parameters and contain a mixture of 8-bit and 16-bit values. The bytes in the 16-bit (2-byte) values are ordered as low-order byte first. The following two blocks of information describe the various files and give needed size and storage information.

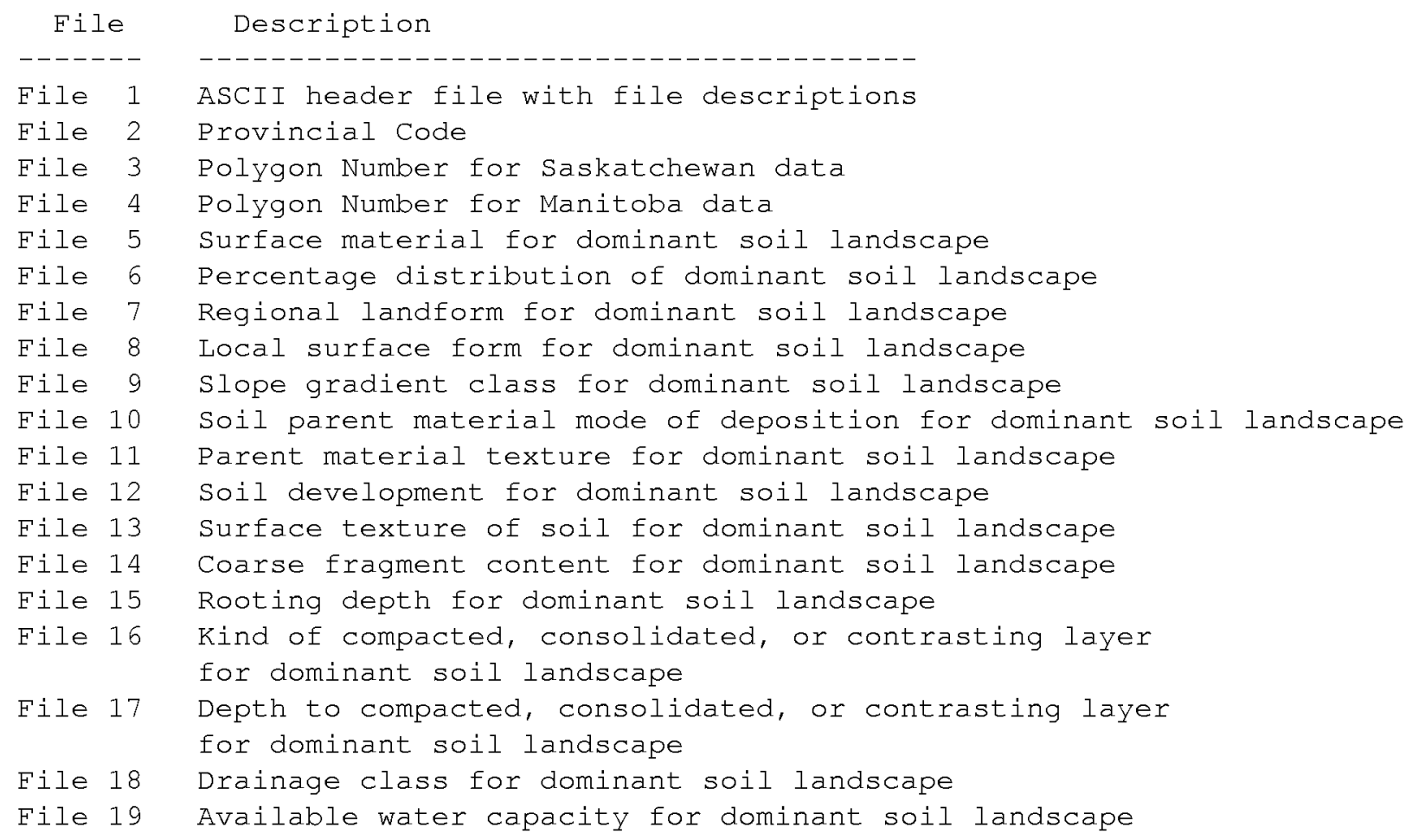


File 20

File 21

File 22

File 23

File 24

File 25

File 26

File 27

File 28

File 29

File 30

File 31

File 32

File 33

File 34

File 35

File 36

File 37

File 38

File 39

File 40

File 41

File 42

File 43

File 44

File 45

File 46

File 47

File 48

File 49

File 50

File 51

File 52

File 53

File 54

File 55

File 56

File 57

File 58

File 59

File 60

File 61

File 62

File 63

File 64

File 65

File 66

File 67

File 68

File 69

File 70
Average depth to water table for dominant soil landscape

Ice type for dominant soil landscape

Ice content for dominant soil landscape

Permafrost occurrence for dominant soil landscape

Active layer depth for dominant soil landscape

Kind of patterned ground for dominant soil landscape

$\mathrm{pH}$ of upper $15 \mathrm{~cm}$ measured with $\mathrm{CaCl}_{2}$ for dominant soil landscape

$\mathrm{pH}$ of upper $15 \mathrm{~cm}$ measured with water for dominant soil landscape

Organic carbon content of upper $15 \mathrm{~cm}$ for dominant soil landscape

Nitrogen content of upper $15 \mathrm{~cm}$ for dominant soil landscape

Thickness of humus layer for dominant soil landscape

Calcareous class of parent material for dominant soil landscape

Inclusions 1 for dominant soil landscape

Inclusions 2 for dominant soil landscape

Vegetative cover or land use for dominant soil landscape

Lake size estimate from Landsat images for dominant soil landscape

Percent of area covered by water bodies for dominant soil landscape

Reliability class for dominant soil landscape

Complexity class for dominant soil landscape

soil name numbers for first dominant soil landscape in saskatchewan

Soil name numbers for first dominant soil landscape in Manitoba

Soil name numbers for second dominant soil landscape in Saskatchewan

Soil name numbers for second dominant soil landscape in Manitoba

Parent material texture group for dominant soil landscape

Surface material for subdominant soil landscape

Percentage distribution of subdominant soil landscape

Regional landform for subdominant soil landscape

Local surface form for subdominant soil landscape

Slope gradient class for subdominant soil landscape

Soil parent material mode of deposition for subdominant soil

landscape

Parent material texture for subdominant soil landscape

Soil development for subdominant soil landscape

Surface texture of soil for subdominant soil landscape

Coarse fragment content for subdominant soil landscape

Rooting depth for subdominant soil landscape

Kind of compacted, consolidated, or contrasting layer

for subdominant soil landscape

Depth to compacted, consolidated, or contrasting layer

for subdominant soil landscape

Drainage class for subdominant soil landscape

Available water capacity for subdominant soil landscape

Average depth to water table for subdominant soil landscape

Ice type for subdominant soil landscape

Ice content for subdominant soil landscape

Permafrost occurrence for subdominant soil landscape

Active layer depth for subdominant soil landscape

Kind of patterned ground for subdominant soil landscape

$\mathrm{pH}$ of upper $15 \mathrm{~cm}$ measured with $\mathrm{CaCl}_{2}$ for subdominant soil landscape

$\mathrm{pH}$ of upper $15 \mathrm{~cm}$ measured with water for subdominant soil landscape

Organic carbon content of upper $15 \mathrm{~cm}$ for subdominant soil landscape

Nitrogen content of upper $15 \mathrm{~cm}$ for subdominant soil landscape

Thickness of humus layer for subdominant soil landscape

Calcareous class of parent material for subdominant soil landscape 


\begin{tabular}{|c|c|c|c|c|}
\hline File 71 & Inclusions 1 for subdominant so & oil landscape & & \\
\hline File 72 & Inclusions 2 for subdominant so & oil landscape & & \\
\hline File & Vegetative cover or land use fo & or subdominan & t soil landsc & zape \\
\hline File 74 & $\begin{array}{l}\text { Lake size estimate from Landsat } \\
\text { landscape }\end{array}$ & t images for & subdominant s & soil \\
\hline File 75 & $\begin{array}{l}\text { Percent of area covered by wate } \\
\text { landscape }\end{array}$ & er bodies for & subdominant & soil \\
\hline File 76 & Reliability class for subdomina & ant soil land & scape & \\
\hline File 77 & Complexity class for subdominan & nt soil lands & cape & \\
\hline File 78 & $\begin{array}{l}\text { Soil name numbers for first sub } \\
\text { Saskatchewan }\end{array}$ & bdominant soi & 1 landscape i. & \\
\hline File & Soil name numbers for first sub & bdominant soi & 1 landscape $i$ & In Manitoba \\
\hline File 80 & $\begin{array}{l}\text { Soil name numbers for second su } \\
\text { Saskatchewan }\end{array}$ & ubdominant so & il landscape & in \\
\hline File 81 & Soil name numbers for second su & ubdominant so & il landscape & in Manitoba \\
\hline File 82 & ASCII Soil Names Supplemental I & Information fc & or Saskatchew & $\operatorname{van}$ \\
\hline File 83 & ASCII Soil Names Supplemental I & Information $\mathrm{f}$ & or Manitoba & \\
\hline File & Original & Number & Number & Bytes per \\
\hline Number & Attribute Name & of pixels & of lines & pixel \\
\hline------ & -------------- & --------- & -------- & --------- \\
\hline 1 & Header File & $\mathrm{N} / \mathrm{A}$ & $\mathrm{N} / \mathrm{A}$ & $\mathrm{N} / \mathrm{A}$ \\
\hline 2 & PROVINCE & 1000 & 1000 & 1 \\
\hline 3 & POLYNUM $\quad(\mathrm{SK})$ & 1000 & 1000 & 2 \\
\hline 4 & POLYNUM $\quad(\mathrm{MN})$ & 1000 & 1000 & 2 \\
\hline 5 & DOMKDMAT & 1000 & 1000 & 1 \\
\hline 6 & DOMDISTR & 1000 & 1000 & 1 \\
\hline 7 & DOMREGFM & 1000 & 1000 & 1 \\
\hline 8 & DOMLOCSE & 1000 & 1000 & 1 \\
\hline 9 & DOMSLOPE & 1000 & 1000 & 1 \\
\hline 10 & DOMPMDEP & 1000 & 1000 & 1 \\
\hline 11 & DOMPMTEX & 1000 & 1000 & 1 \\
\hline 12 & DOMDEVEL & 1000 & 1000 & 1 \\
\hline 13 & DOMSRFTX & 1000 & 1000 & 1 \\
\hline 14 & DOMCFRAG & 1000 & 1000 & 1 \\
\hline 15 & DOMROOT & 1000 & 1000 & 1 \\
\hline 16 & DOMCMP LR & 1000 & 1000 & 1 \\
\hline 17 & DOMCMPDP & 1000 & 1000 & 1 \\
\hline 18 & DOMDRAIN & 1000 & 1000 & 1 \\
\hline 19 & DOMAVWAT & 1000 & 1000 & 1 \\
\hline 20 & DOMWATAB & 1000 & 1000 & 1 \\
\hline 21 & DOMICETY & 1000 & 1000 & 1 \\
\hline 22 & DOMICECT & 1000 & 1000 & 1 \\
\hline 23 & DOMPERMA & 1000 & 1000 & 1 \\
\hline 24 & DOMACTLR & 1000 & 1000 & 1 \\
\hline 25 & DOMPATGD & 1000 & 1000 & 1 \\
\hline 26 & DOMPHCAL & 1000 & 1000 & 1 \\
\hline 27 & DOMPHWAT & 1000 & 1000 & 1 \\
\hline 28 & DOMORGAN & 1000 & 1000 & 1 \\
\hline 29 & DOMNITRO & 1000 & 1000 & 1 \\
\hline 30 & DOMHUMLR & 1000 & 1000 & 1 \\
\hline 31 & DOMCALCA & 1000 & 1000 & 1 \\
\hline 32 & DINCLUS1 & 1000 & 1000 & 1 \\
\hline 33 & DINCLUS2 & 1000 & 1000 & 1 \\
\hline
\end{tabular}

Page 44 


\begin{tabular}{|c|c|c|c|c|c|c|}
\hline 34 & DOMVEGET & & 1000 & 1000 & 1000 & 1 \\
\hline 35 & DOMLAKE & & 1000 & 1000 & 1000 & 1 \\
\hline 36 & DOMWATBD & & 1000 & 1000 & 1000 & 1 \\
\hline 37 & DOMRELIA & & 1000 & 1000 & 1000 & 1 \\
\hline 38 & DOMCOMP L & & 1000 & 1000 & 1000 & 1 \\
\hline 39 & DOMNAME 1 & (SK) & 2000 & 1000 & 1000 & 2 \\
\hline 40 & DOMNAME 1 & $(\mathrm{MN})$ & 2000 & 1000 & 1000 & 2 \\
\hline 41 & DOMNAME2 & (SK) & 2000 & 1000 & 1000 & 2 \\
\hline 42 & DOMNAME2 & $(\mathrm{MN})$ & 2000 & 1000 & 1000 & 2 \\
\hline 43 & DOMTEXGP & & 1000 & 1000 & 1000 & 1 \\
\hline 44 & SUBKDMAT & & 1000 & 1000 & 1000 & 1 \\
\hline 45 & SUBDISTR & & 1000 & 1000 & 1000 & 1 \\
\hline 46 & SUBREGFM & & 1000 & 1000 & 1000 & 1 \\
\hline 47 & SUBLOCSF & & 1000 & 1000 & 1000 & 1 \\
\hline 48 & SUBSLOPE & & 1000 & 1000 & 1000 & 1 \\
\hline 49 & SUBPMDEP & & 1000 & 1000 & 1000 & 1 \\
\hline 50 & SUBPMTEX & & 1000 & 1000 & 1000 & 1 \\
\hline 51 & SUBDEVEL & & 1000 & 1000 & 1000 & 1 \\
\hline 52 & SUBSRFTX & & 1000 & 1000 & 1000 & 1 \\
\hline 53 & SUBCFRAG & & 1000 & 1000 & 1000 & 1 \\
\hline 54 & SUBROOT & & 1000 & 1000 & 1000 & 1 \\
\hline 55 & SUBCMP LR & & 1000 & 1000 & 1000 & 1 \\
\hline 56 & SUBCMPDP & & 1000 & 1000 & 1000 & 1 \\
\hline 57 & SUBDRAIN & & 1000 & 1000 & 1000 & 1 \\
\hline 58 & SUBAVWAT & & 1000 & 1000 & 1000 & 1 \\
\hline 59 & SUBWATAB & & 1000 & 1000 & 1000 & 1 \\
\hline 60 & SUBICETY & & 1000 & 1000 & 1000 & 1 \\
\hline 61 & SUBICECT & & 1000 & 1000 & 1000 & 1 \\
\hline 62 & SUBPERMA & & 1000 & 1000 & 1000 & 1 \\
\hline 63 & SUBACTLR & & 1000 & 1000 & 1000 & 1 \\
\hline 64 & SUBPATGD & & 1000 & 1000 & 1000 & 1 \\
\hline 65 & SUBPHCAL & & 1000 & 1000 & 1000 & 1 \\
\hline 66 & SUBPHWAT & & 1000 & 1000 & 1000 & 1 \\
\hline 67 & SUBORGAN & & 1000 & 1000 & 1000 & 1 \\
\hline 68 & SUBNITRO & & 1000 & 1000 & 1000 & 1 \\
\hline 69 & SUBHUMLR & & 1000 & 1000 & 1000 & 1 \\
\hline 70 & SUBCALCA & & 1000 & 1000 & 1000 & 1 \\
\hline 71 & SINCLUSI & & 1000 & 1000 & 1000 & 1 \\
\hline 72 & SINCLUS2 & & 1000 & 1000 & 1000 & 1 \\
\hline 73 & SUBVEGET & & 1000 & 1000 & 1000 & 1 \\
\hline 74 & SUBLAKE & & 1000 & 1000 & 1000 & 1 \\
\hline 75 & SUBWATBD & & 1000 & 1000 & 1000 & 1 \\
\hline 76 & SUBRELIA & & 1000 & 1000 & 1000 & 1 \\
\hline 77 & SUBCOMP L & & 1000 & 1000 & 1000 & 1 \\
\hline 78 & SUBNAME 1 & (SK) & 2000 & 1000 & 1000 & 2 \\
\hline 79 & SUBNAME1 & (MN) & 2000 & 1000 & 1000 & 2 \\
\hline 80 & SUBNAME2 & (SK) & 2000 & 1000 & 1000 & 2 \\
\hline 81 & SUBNAME2 & $(\mathrm{MN})$ & 2000 & 1000 & 1000 & 2 \\
\hline 82 & Sask Soil & Names & 150 & $\mathrm{~N} / \mathrm{A}$ & $\mathrm{N} / \mathrm{A}$ & $N / A$ \\
\hline 83 & Mani Soil & Names & 110 & $\mathrm{~N} / \mathrm{A}$ & $\mathrm{N} / \mathrm{A}$ & $\mathrm{N} / \mathrm{A}$ \\
\hline
\end{tabular}

Page 45 


\subsubsection{Compressed CD-ROM Files}

On the BOREAS CD-ROMs, files 1, 82, and 83 listed above are stored as ASCII text files; however, files 2 through 81 have been compressed with the Gzip compression program (file name *.gz). These data have been compressed using gzip version 1.2.4 and the high compression (-9) option (Copyright (C) 1992-1993 Jean-loup Gailly). Gzip (GNU zip) uses the Lempel-Ziv algorithm (Welch, 1994) used in the zip and PKZIP programs. The compressed files may be uncompressed using gzip (-d option) or gunzip. Gzip is available from many Web sites (for example, ftp site prep.ai.mit.edu/pub/gnu/gzip-**) for a variety of operating systems in both executable and source code form. Versions of the decompression software for various systems are included on the CD-ROMs.

\section{Data Manipulations}

\subsection{Formulae}

None.

\subsubsection{Derivation Techniques and Algorithms}

None.

\subsection{Data Processing Sequence}

\subsubsection{Processing Steps}

BORIS staff gridded each attribute for the provinces of Saskatchewan and Manitoba and combined the layers for these two provinces into one layer for each attribute, except for the polygon number and soil name layers.

BORIS staff processed the regional soils data by following these steps for each attribute:

- $\quad$ Reproject the vector data for the provinces of Saskatchewan and Manitoba to the BOREAS grid projection.

- $\quad$ Rasterize the vector files.

- Combine the Saskatchewan and Manitoba layers to produce one gridded layer.

- Write the gridded layer to tape.

- Copy the ASCII and compress the binary files for release on CD-ROM.

\subsubsection{Processing Changes}

None.

\subsection{Calculations}

\subsubsection{Special Corrections/Adjustments}

None.

\subsubsection{Calculated Variables}

None.

\subsection{Graphs and Plots}

None. 


\section{Errors}

\subsection{Sources of Error}

Potential sources of error in the original data set include interpretation or digitizing error as well as coding and keying errors in the attributes. There is also the possibility that the data could have been gridded incorrectly, although visual inspection of the data was done to prevent this.

\subsection{Quality Assessment}

\subsubsection{Data Validation by Source}

Each gridded file/layer was spot checked to make sure that the gridding procedure assigned a digital number (DN) to each attribute value.

\subsubsection{Confidence Level/Accuracy Judgment}

The accuracy of the gridding procedure is high, although some consideration should be given to the scale of the data and what will be inferred from it in order to understand the accuracy of the original data.

The source in Canada from whom these data were received has strong caveats about the use of the data. These data are constantly being updated as new data are collected and become available. These data represent broad generalizations about the soil characteristics of this area. Caution should be used when inferring information from these data.

\subsubsection{Measurement Error for Parameters}

Unknown.

\subsubsection{Additional Quality Assessments}

Unknown.

\subsubsection{Data Verification by Data Center}

As noted previously, BORIS personnel reviewed the data layers visually as vector plots and raster data layers. Direct quantitative checking of the data was not performed.

\section{Notes}

\subsection{Limitations of the Data}

The original data were received in two parts: Saskatchewan and Manitoba. The gridded data represent a merging of these two data sets. Unfortunately, many of the attributes along the border have different values. Therefore, a sharp discontinuity exists along the border in many of the files caused by different interpretations by those who created the maps for the different provinces. CanSIS has plans to resolve these problem areas along the provincial boundaries.

\subsection{Known Problems with the Data}

The discontinuity of polygons along the provincial boundary can be a potential problem for some users. See Section 11.1 for more information on this problem.

\subsection{Usage Guidance}

Before uncompressing the Gzip files on CD-ROM, be sure that you have enough disk space to hold the uncompressed data files. Then use the appropriate decompression program provided on the CD-ROM for your specific system.

\subsection{Other Relevant Information None.}




\section{Application of the Data Set}

The documentation for the original data listed the following uses for which these data were intended:

- Assess the productivity of the land nationally or over large regions.

- $\quad$ Find areas that have actual or potential problems affecting land use, such as salinity or susceptibility to erosion, and assess the severity.

- Locate general areas that may be suitable for particular types of land use, which can be selected for more detailed investigations.

- Apply general research findings and agrotechnology procedures that are successful in one part of the country to other areas that have similar attributes.

- Link soil and land information with other data bases, such as information on climate, economics, or census, for assessing land use on a regional, national, or even an international scale.

- $\quad$ Educate geography students at colleges or universities.

\section{Future Modifications and Plans}

CanSIS has plans to resolve the problem areas along the provincial boundaries.

\section{Software}

\subsection{Software Description}

BORIS staff used the ARC/INFO (Version 7) software and related tools to process the original vector data to this raster form. The ARC/INFO software is a proprietary package developed and distributed by:

Environmental Systems Research Institute, Inc. (ESRI)

380 New York St.

Redlands, CA 92373-8100

Gzip (GNU zip) uses the Lempel-Ziv algorithm (Welch, 1994) used in the zip and PKZIP commands.

\subsection{Software Access}

ARC/INFO is a commercial package; contact ESRI for details. Gzip is available from many Web sites across the Internet (for example, ftp site prep.ai.mit.edu/pub/gnu/gzip-***) for a variety of operating systems in both executable and source code form. Versions of the decompression software for various systems are included on the CD-ROMs.

\section{Data Access}

The BOREAS regional soils data in raster format and AEAC projection are available from the Earth Observing System Data and Information System (EOSDIS) Oak Ridge National Laboratory (ORNL) Distributed Active Archive Center (DAAC). 


\subsection{Contact Information}

For BOREAS data and documentation please contact:

ORNL DAAC User Services

Oak Ridge National Laboratory

P.O. Box 2008 MS-6407

Oak Ridge, TN 37831-6407

Phone: (423) 241-3952

Fax: (423) 574-4665

E-mail: ornldaac@ornl.gov or ornl@eos.nasa.gov

\subsection{Data Center Identification}

Earth Observing System Data and Information System (EOSDIS) Oak Ridge National Laboratory (ORNL) Distributed Active Archive Center (DAAC) for Biogeochemical Dynamics http://www-eosdis.ornl.gov/.

\subsection{Procedures for Obtaining Data}

Users may obtain data directly through the ORNL DAAC online search and order system [http://www-eosdis.ornl.gov/] and the anonymous FTP site [ftp://www-eosdis.ornl.gov/data/] or by contacting User Services by electronic mail, telephone, fax, letter, or personal visit using the contact information in Section 15.1.

\subsection{Data Center Status/Plans}

The ORNL DAAC is the primary source for BOREAS field measurement, image, GIS, and hardcopy data products. The BOREAS CD-ROM and data referenced or listed in inventories on the CD-ROM are available from the ORNL DAAC.

\section{Output Products and Availability}

\subsection{Tape Products}

These data can be made available on 8-mm, Digital Archive Tape (DAT), or 9-track tapes at 1600 or 6250 Bytes Per Inch (BPI).

\subsection{Film Products}

None available from BORIS; see Section 11.4, Other Relevant Information.

\subsection{Other Products}

These data are available on the BOREAS CD-ROM series.

\section{References}

\subsection{Platform/Sensor/Instrument/Data Processing Documentation}

ARC/INFO User's Guide (Version 7). 1994. Redlands, CA.

Welch, T.A. 1984. A Technique for High Performance Data Compression. IEEE Computer, Vol. 17, No. 6, pp. 8-19. 


\subsection{Journal Articles and Study Reports}

Acton, D.F., G.A. Padbury, and J.A. Shields. 1991. Soil Landscapes of Canada-Saskatchewan Digital Map Data; Scale 1:1000000; CanSIS No. SK018200, Version 90.11.30; CLBRR Archive, Agriculture Canada, Research Branch, Ottawa, Canada. (CLBRR Contribution No. 91-107D).

Agriculture Canada Expert Committee on Soil Survey. 1987. The Canadian system of soil classification, 2nd ed. Agric. Can. Publ. 1646, 164 pp.

Brown, R.J.E. 1970. Permafrost in Canada: Its influence on northern development. University of Toronto Press, Toronto, Ont., 234 pp.

Brown, R.J.E. 1978. Permafrost map of Canada. Plate No. 32 in Hydrological atlas of Canada. Dept. of Fisheries and Environment, Ottawa, Ont.

De Jong, R., J.A. Shields, and W. K. Sly. 1984. Estimated soil water reserves applicable to a wheat-fallow rotation for generalized soil areas mapped in southern Saskatchewan. Canadian Journal of Soil Science 64:667-680.

Expert Committee on Soil Survey. 1982. The Canada soil information system (CanSIS) manual for describing soils in the field, revised. Land Resource Research Institute, Research Branch, Agriculture Canada, Ottawa, Ont. 166 pp.

Geoanalysis Ltd. 1981. Landform descriptive classes for higher levels of ecological land classification. S. Ringrose, ed. Contract No. KL229-0-4581, Lands Directorate, Environment Canada, 18 pp.

Manitoba-Canada Soil Survey Unit. 1990. Soil Landscapes of Canada-Manitoba; Digital Map Data; Scale 1:1000000; CanSIS No. MN068200, Version 91.03.31; CLBRR Archive, Agriculture Canada, Research Branch, Ottawa, Canada (CLBRR Contribution No. 91-109D).

Mills G.F., MDA; R.G. Eilers, R.E. Smith, W. Michalyna, H. Veldhuis, W. Fraser, CDA. 1990. Soil Landscapes of Canada-Manitoba; Soil landscapes polygon attribute digital data; CanSIS No. MN068200, Version 91.03.31; CLBRR Archive, Agriculture Canada, Research Branch, Ottawa, Canada (CLBRR Contribution No. 91-110D).

Newcomer, J., D. Landis, S. Conrad, S. Curd, K. Huemmrich, D. Knapp, A. Morrell, J. Nickeson, A. Papagno, D. Rinker, R. Strub, T. Twine, F. Hall, and P. Sellers, eds. 2000. Collected Data of The Boreal Ecosystem-Atmosphere Study. NASA. CD-ROM.

Padbury, G.A. and J.A. Shields. 1991. Soil Landscapes of Canada-Saskatchewan Soil Landscapes Polygon Attribute Digital Data. CanSIS No. SK018200, Version 90.11.30; CLBRR Archive, Agriculture Canada, Research Branch, Ottawa, Canada (CLBRR Contribution No. 91-108D).

Permafrost Subcommittee, Associate Committee on Geotechnical Research. 1988. Glossary of permafrost and related ground-ice terms. National Research Council of Canada, Ottawa, Ont., Technical Memorandum No. 142, 156 pp.

Research Branch, Agriculture Canada. 1976. Glossary of terms in soil science. Research Branch, Canada Department of Agriculture, Ottawa, Ont., Publication 1459, 44 pp.

Sellers, P. and F. Hall. 1994. Boreal Ecosystem-Atmosphere Study: Experiment Plan. Version 1994-3.0, NASA BOREAS Report (EXPLAN 94).

Sellers, P. and F. Hall. 1996. Boreal Ecosystem-Atmosphere Study: Experiment Plan. Version 1996-2.0, NASA BOREAS Report (EXPLAN 96). 
Sellers, P., F. Hall, and K.F. Huemmrich. 1996. Boreal Ecosystem-Atmosphere Study: 1994 Operations. NASA BOREAS Report (OPS DOC 94).

Sellers, P., F. Hall, and K.F. Huemmrich. 1997. Boreal Ecosystem-Atmosphere Study: 1996 Operations. NASA BOREAS Report (OPS DOC 96).

Sellers, P., F. Hall, H. Margolis, B. Kelly, D. Baldocchi, G. den Hartog, J. Cihlar, M.G. Ryan, B. Goodison, P. Crill, K.J. Ranson, D. Lettenmaier, and D.E. Wickland. 1995. The boreal ecosystem-atmosphere study (BOREAS): an overview and early results from the 1994 field year. Bulletin of the American Meteorological Society. 76(9):1549-1577.

Sellers, P.J., F.G. Hall, R.D. Kelly, A. Black, D. Baldocchi, J. Berry, M. Ryan, K.J. Ranson, P.M. Crill, D.P. Lettenmaier, H. Margolis, J. Cihlar, J. Newcomer, D. Fitzjarrald, P.G. Jarvis, S.T. Gower, D. Halliwell, D. Williams, B. Goodison, D.E. Wickland, and F.E. Guertin. 1997. BOREAS in 1997: Experiment Overview, Scientific Results and Future Directions. Journal of Geophysical Research 102(D24): 28,731-28,770.

Shields J.A., C. Tarnocai, K.W.G. Valentine, and K.B. MacDonald. 1991. Soil landscapes of Canada-Procedures Manual and User's Handbook. Land Resource and Research Centre, Agriculture Canada, Ottawa, Canada (Publication 1868/E, LRRC Contribution Number: 88-29).

\subsection{Archive/DBMS Usage Documentation \\ None.}

\section{Glossary of Terms}

None.

\section{List of Acronyms}

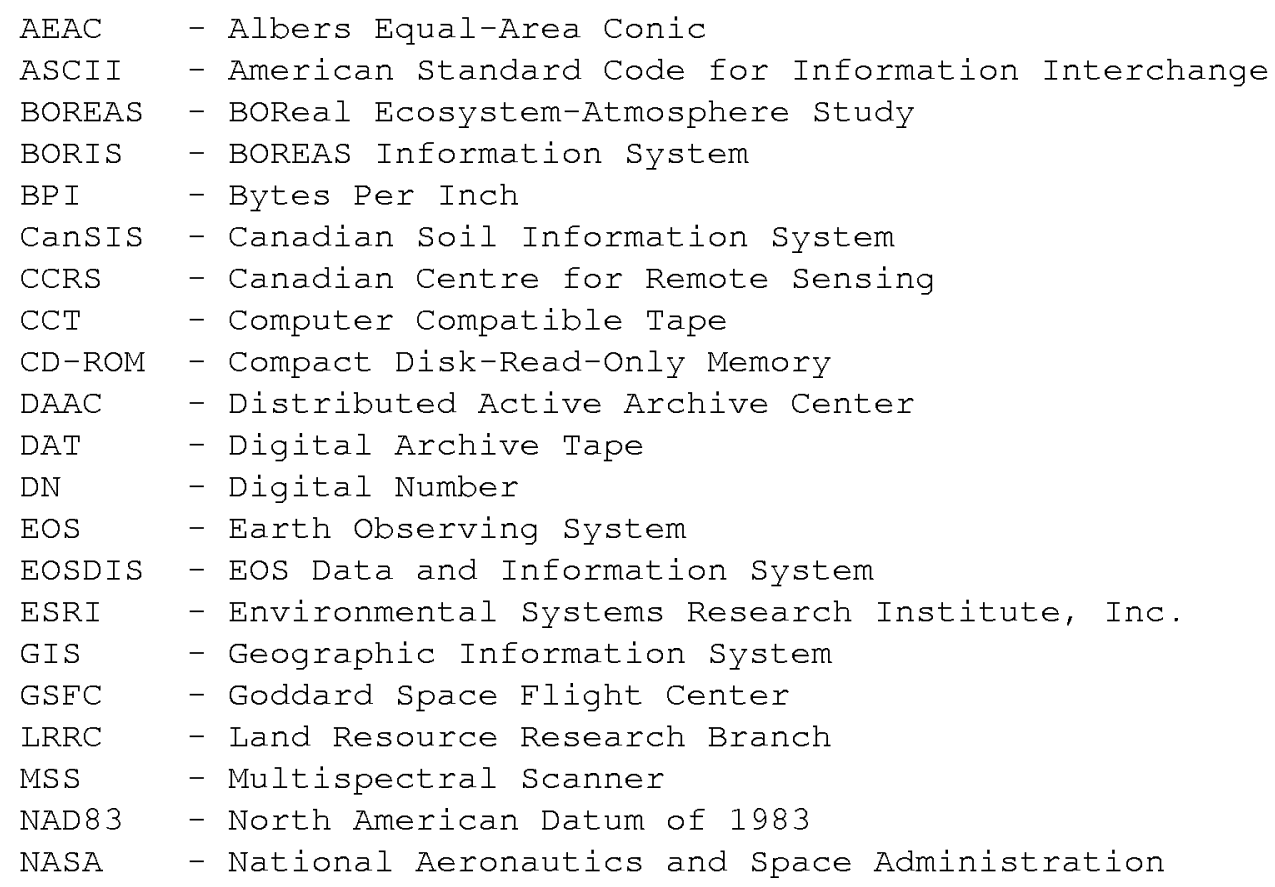




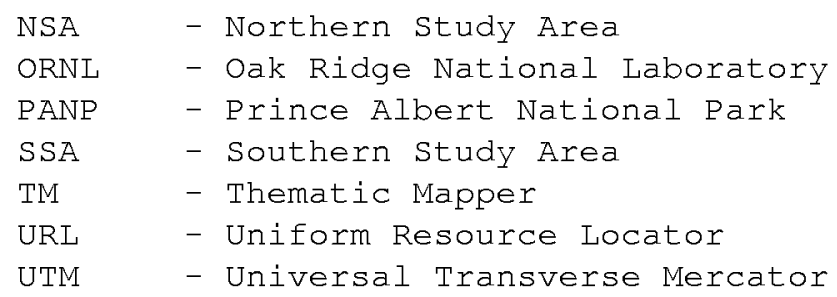

\section{Document Information}

\subsection{Document Revision Dates}

Written: 02-Dec-1994

Last Updated: 30-Apr-1999

\subsection{Document Review Dates}

BORIS Review: 28-Jul-1997

Science Review:

\subsection{Document ID}

\subsection{Citation}

When using these data, please include the following acknowledgment as well as citations of relevant papers in Section 17.2:

The original data were provided by Agriculture Canada. The vector data were processed and gridded by BORIS staff. The contribution of the vector data by Agriculture Canada and the processing of the data by BORIS staff are greatly appreciated.

If using data from the BOREAS CD-ROM series, also reference the data as:

BOREAS Staff Science, "BOREAS Staff Science GIS Data Collection Program." In Collected Data of The Boreal Ecosystem-Atmosphere Study. Eds. J. Newcomer, D. Landis, S. Conrad, S. Curd, K. Huemmrich, D. Knapp, A. Morrell, J. Nickeson, A. Papagno, D. Rinker, R. Strub, T. Twine, F. Hall, and P. Sellers. CD-ROM. NASA, 2000.

Also, cite the BOREAS CD-ROM set as:

Newcomer, J., D. Landis, S. Conrad, S. Curd, K. Huemmrich, D. Knapp, A. Morrell, J. Nickeson, A. Papagno, D. Rinker, R. Strub, T. Twine, F. Hall, and P. Sellers, eds. Collected Data of The Boreal Ecosystem-Atmosphere Study. NASA. CD-ROM. NASA, 2000.

\subsection{Document Curator}

\subsection{Document URL}


Public reporting burden for this collection of information is estimated to average 1 hour per response, including the time for reviewing instructions, searching existing data sources, gathering and maintaining the data needed and completing and reviewing the collection of information. Send comments regarding this burden estimate or any other aspect of this collection of information including suggestions for reducing this burden, to Washington Headquaters Services, Directorate for Information Operations and Reports, 1215 Jefferson Davis Highway, Suite 1204, Arlington, VA 22202-4302, and to the Office of Management and Budget, Paperwork Reduction Project (0704-0188). Washington, DC 20503.

\begin{tabular}{|l|l|l|}
\hline 1. AGENCY USE ONLY (Leave blank) & 2. REPORT DATE & 3. REPORT TYPE AND DATES COVERED
\end{tabular}

4. TITLE AND SUBTITLE

September 2000

Technical Memorandum

Technical Report Series on the Boreal Ecosystem-Atmosphere Study (BOREAS) BOREAS Regional Soils Data in Raster Format and AEAC Projection

5. FUNDING NUMBERS

6. AUTHOR(S)

Bryan Monette amd David Knapp

Forrest G. Hall, Editor

7. PERFORMING ORGANIZATION NAME(S) AND ADDRESS (ES)

Goddard Space Flight Center

Greenbelt, Maryland 20771

923

RTOP: 923-462-33-01
9. SPONSORING / MONITORING AGENCY NAME(S) AND ADDRESS (ES)

National Aeronautics and Space Administration

Washington, DC 20546-0001
8. PEFORMING ORGANIZATION REPORT NUMBER

2000-03136-0

\section{SUPPLEMENTARY NOTES}

B. Monette: Agriculture Canada, Ottawa, Ontario, Canada;

D. Knapp: Raytheon ITSS, NASA Goddard Space Flight Center, Greenbelt, Maryland

\begin{tabular}{l|l}
\hline 12a. DISTRIBUTION / AVAILABILITY STATEMENT & 12b. DISTRIBUTION CODE \\
Unclassified-Unlimited & \\
Subject Category: 43 & \\
Report available from the NASA Center for AeroSpace Information, \\
7121 Standard Drive, Hanover, MD 21076-1320. (301) $621-0390$.
\end{tabular}

13. ABSTRACT (Maximum 200 words)

This data set was gridded by BORIS Staff from a vector data set received from the Canadian Soil Information System (CanSIS). The original data came in two parts that covered Saskatchewan and Manitoba. The data were gridded and merged into one data set of 84 files covering the BOREAS region. The data were gridded into the AEAC projection. Because the mapping of the two provinces was done separately in the original vector data, there may be discontinuities in some of the soil layers because of different interpretations of certain soil properties. The data are stored in binary, image format files.

14. SUBJECT TERMS

BOREAS, remote sensing science.
0. SPONSORING / MONITORING

TM-2000-209891

Vol. 109

format files.

18. SECURITY CLASSIFICATION
OF THIS PAGE
Unclassified

19. SECURITY CLASSIFICATION OF ABSTRACT

Unclassified
15. NUMBER OF PAGES

52

16. PRICE CODE
20. LIMITATION OF ABSTRACT

$\mathrm{UL}$ 
